OPEN ACCESS

Edited by:

Frank Rasche,

University of Hohenheim, Germany

Reviewed by:

Moez Hanin,

University of Sfax, Tunisia

Zakira Naureen,

University of Nizwa, Oman

*Correspondence:

Hassan Etesam

hassanetesami@ut.ac.ir

Specialty section:

This article was submitted to

Terrestrial Microbiology,

a section of the journal

Frontiers in Microbiology

Received: 05 October 2017

Accepted: 23 January 2018

Published: 08 February 2018

Citation:

Etesami H and Beattie GA (2018)

Mining Halophytes for Plant

Growth-Promoting Halotolerant

Bacteria to Enhance the Salinity

Tolerance of Non-halophytic Crops.

Front. Microbiol. 9:148

doi: 10.3389/fmicb.2018.00148

\section{Mining Halophytes for Plant Growth-Promoting Halotolerant Bacteria to Enhance the Salinity Tolerance of Non-halophytic Crops}

\author{
Hassan Etesami ${ }^{1 *}$ and Gwyn A. Beattie ${ }^{2}$ \\ ${ }^{1}$ Department of Soil Science, Faculty of Agricultural Engineering \& Technology, University of Tehran, Tehran, Iran, \\ ${ }^{2}$ Department of Plant Pathology and Microbiology, lowa State University, Ames, IA, United States
}

Salinity stress is one of the major abiotic stresses limiting crop production in arid and semi-arid regions. Interest is increasing in the application of PGPRs (plant growth promoting rhizobacteria) to ameliorate stresses such as salinity stress in crop production. The identification of salt-tolerant, or halophilic, PGPRs has the potential to promote saline soil-based agriculture. Halophytes are a useful reservoir of halotolerant bacteria with plant growth-promoting capabilities. Here, we review recent studies on the use of halophilic PGPRs to stimulate plant growth and increase the tolerance of non-halophytic crops to salinity. These studies illustrate that halophilic PGPRs from the rhizosphere of halophytic species can be effective bio-inoculants for promoting the production of non-halophytic species in saline soils. These studies support the viability of bioinoculation with halophilic PGPRs as a strategy for the sustainable enhancement of non-halophytic crop growth. The potential of this strategy is discussed within the context of ensuring sustainable food production for a world with an increasing population and continuing climate change. We also explore future research needs for using halotolerant PGPRs under salinity stress.

Keywords: salinity, salinity-sensitive crop, halophytes, salt-tolerant, halophilic PGPRs, saline soil-based agriculture

\section{INTRODUCTION}

Food security is a fundamental need of all societies. The global population is projected to increase to around 10 billion people within the next 50 years (Godfray et al., 2010). To meet the additional food demand, an estimated 50\% increase in yields of the major food crops will be required (Godfray et al., 2010). Whereas, the world's population is increasing, agricultural soils are decreasing about $1-2 \%$ every year in global arid and semi-arid zones due to soil salinity (Kafi and Khan, 2008). The low rainfall and high temperature characteristic of these zones promote high salinity (Shrivastava and Kumar, 2015), and this salinity has become an important factor limiting the growth of salt-sensitive plants and even some halophytes (Hasegawa et al., 2000; Sobhanian et al., 2011). Salinity stress has resulted in up to a $70 \%$ decrease in yield of important crops like wheat, maize, rice, and barley (Acquaah, 2007). Moreover, salinity stress is predicted to increase further in many regions due to global climate change. The costs associated with this stress are potentially enormous, estimated at US\$12 billion per annum globally, and rising (Qadir et al., 2008; Dodd and Pérez-Alfocea, 2012).

A decrease in the availability of fertile land and the consequent extensive reuse of irrigated lands have driven the rapid development of saline soil-based agriculture in recent years 
(Zhu et al., 2011). Whereas, plants that are salt-resistant can produce significant yields in saline soils, many agricultural crops, and trees exhibit a low tolerance to salt (Glenn et al., 1991). Future agricultural production in these salt-affected agricultural environments thus requires the development of salt-tolerant food and fiber crops (Rozema and Flowers, 2008; Joshi et al., 2015). Traditional breeding and genetic engineering approaches have had only limited successes in developing salinity-resistant plants, despite significant efforts (Munns and Tester, 2008; Schubert et al., 2009; Dodd and Pérez-Alfocea, 2012; Joshi et al., 2015; Krishna et al., 2015). These efforts are complicated by the fact that salinity affects several facets of plant physiology (Dodd and Pérez-Alfocea, 2012; Kumari et al., 2015).

An alternative strategy to crop improvement to enhance salt tolerance may be to introduce salt-tolerant microbes that augment crop growth (Dodd and Pérez-Alfocea, 2012). Soil salinity-tolerant microorganisms have been found to increase the growth of many crops grown in salt-affected soils, which suggests that this approach may succeed where developing salt-tolerant germplasm has not (Dodd and Pérez-Alfocea, 2012). Identifying and using salinity-tolerant microorganisms could not only enhance the salt tolerance of crops but also reduce pressure on arable lands. Among the microorganisms associated with plants, plant growth-promoting rhizobacteria (PGPRs) have been effective at improving plant stress tolerance (Etesami and Beattie, 2017; Etesami, 2018). Yang et al. (2009) coined the term "Induced Systemic Tolerance" to describe the tolerance to abiotic stresses that is elicited by PGPRs in plants. Previous reports have reviewed the effects of PGPRs in relieving abiotic stress in various crop plants (Dutta and Khurana, 2015; Etesami and Beattie, 2017). The ability of PGPRs to transform nutrients and increase plant tolerance to abiotic stress is influenced by environmental conditions, including the climate, weather, and soil characteristics (e.g., high salinity), and by interactions with other microbial flora in the soil (Giongo et al., 2008). For example, the performance of phosphorus-solubilizing microorganisms (PSMs) is strongly affected by environmental factors, especially stress factors (Yoon et al., 2001; Sánchez-Porro et al., 2009). Upadhyay et al. (2009) found that PGPRs lose plant growth-promoting (PGP) traits with increasing salinity in vitro. Thus, the use of halotolerant PGPRs that are selected based on both high salt tolerance and efficiency in expressing PGP traits could significantly advance our ability to grow crops in environments with natural or induced salinity (Zhu et al., 2011). Rhizobacteria isolated from saline habitats have been shown to be more efficient at enhancing plant tolerance to salt than PGPRs isolated from non-saline habitats (Paul and Nair, 2008; Egamberdieva and Kucharova, 2009; Khan et al., 2016). There is now clear evidence that PGPRs associated with plants growing in harsh environmental conditions help those plants tolerate abiotic stresses (Lucero et al., 2008, 2011; Rodriguez et al., 2008; Lau and Lennon, 2012; Marasco et al., 2012; Kaplan et al., 2013). Moreover, recent advances in plant-bacterial interactions indicate that plants can shape the microbiome in the rhizosphere and endosphere (i.e., the zone within the roots; Berendsen et al., 2012). Under stress conditions, plants can require the presence of associated bacteria to tolerate stress and therefore grow and become established in an ecosystem (Hardoim et al., 2008). Symbiotic bacteria exist in all plants, and this relationship may be a key factor involved in plant stress tolerance. In fact, local adaptation of plants to their environment is driven by the genetic differentiation among closely associated PGPRs (Rodriguez and Redman, 2008). Transplanting various plant species in the absence of bacteria is notoriously difficult (Leifert et al., 1989), and this difficulty supports the importance of bacteria to plant growth, including under stressful conditions.

Halophytes are extremely salt tolerant plants-they usually grow and survive in environments with salinity concentrations as high as $5 \mathrm{~g} \mathrm{l}^{-1}$ (Joshi et al., 2015). Halophytes play an important role in protecting ecosystems due to their remediation abilities. Halophytic plants have evolved various strategies to live in saline environments. These strategies include the production of compatible solutes to increase the osmotic pressure in the cytoplasm, the accumulation of $\mathrm{Na}^{+}$in the vacuole, and the exclusion of $\mathrm{Na}^{+}$from cells (Flowers and Colmer, 2008). They also have evolved an ability to exploit the benefits provided by endophytes and rhizosphere microorganisms (Sgroy et al., 2009; Ruppel et al., 2013).

The rhizosphere of halophytic plants serves as a reservoir for various groups of salt-tolerant rhizobacteria that could enhance the growth of crops under salinity stress (Jha et al., 2012, 2015; Shukla et al., 2012; Bharti et al., 2013; Ramadoss et al., 2013; Goswami et al., 2014; Sharma et al., 2016; Yuan et al., 2016). Like halophytic plants, salt-tolerant rhizobacteria have evolved various strategies to live in high saline environments. An important strategy is the ability to accumulate compatible osmolytes to maintain intracellular osmotic balance (Nabti et al., 2015; Sharma et al., 2016). These bacteria exhibit multiple stress-related traits that may contribute to their plant protective capabilities under growth inhibiting levels of salt (Rohban et al., 2009; Siddikee et al., 2010; Bharti et al., 2013; Sharma et al., 2016). In this review, we present the attempts thus far to isolate halotolerant PGPRs that bestow salt tolerance to agricultural crops. We offer a view of the ability of PGPRs to increase plant tolerance to salt and facilitate plant growth, as well as their potential to be isolated from the rhizosphere of halophytes. Lastly, we highlight the future application of these PGPRs as bioinoculants in saline soil-based agriculture. A key concept in this review is that the range of PGPRs with multiple PGP traits that exist in the rhizosphere of halophytic plants is a valuable resource for improving crop tolerance to salinity and promoting saline soil-based agriculture in the future.

\section{HALOPHYTES}

Plants can grow at high levels of soil salinity although the extent of growth inhibition varies among plant species. Plants are classified into glycophytes (salt-sensitive plants) and halophytes (salt-loving plants) based on their tolerance to salinity. Halophytes are plants which naturally survive in salt-contaminated environments and can tolerate salinity concentrations as high as $1 \mathrm{M} \mathrm{NaCl}$ (Flowers and Colmer, 2008; Kumari et al., 2015). About $1 \%$ of the total flora of the world 
(both dicots and monocots) are halophytic plants. These are distributed primarily in arid, semi-arid inlands, and high salinity wetlands along the tropical and sub-tropical coasts (Kumari et al., 2015). Halophytes have salt-responsive genes and proteins to counteract the adverse effects of salinity, while glycophytes cannot tolerate high salinity (Askari et al., 2006; Yu et al., 2011). Depending on their resistance and demand for sodium salts $(\mathrm{NaCl})$, halophyte plants can be known as obligate or facultative halophytes (Kumari et al., 2015). Facultative halophytes can grow under freshwater conditions, whereas obligate halophytes need some salt to survive and grow (Kumari et al., 2015). Hydro-halophytes and xero-halophytes are another division for halophytes. Hydro-halophytes can grow in aquatic conditions or on wet soil, and xero-halphytes can grow in habitats where the soil is always saline and dry (Kumari et al., 2015). Most herbal varieties in desert areas are xero-halophytes and many of them are succulent (Kumari et al., 2015). Because halophytes flourish in high salinity conditions, they are considered to be extremophiles (Kosová et al., 2013).

Halophytes employ several mechanisms to adjust to soil salinity (Shabala, 2013; Zhang and Shi, 2013; Flowers and Colmer, 2015; Joshi et al., 2015; Kumari et al., 2015). These mechanisms include complex molecular, biochemical, physiological, and morphological changes (Wang et al., 2001) such as (i) modulating plant hormones (Parida and Das, 2005; Gupta and Huang, 2014) like IAA, jasmonic acid (JA), gibberellin (GA), ethylene (ET), and abscisic acid (ABA), and inducing enzymes related to their biosynthesis; (ii) synthesizing compatible solutes and osmoprotectants (Sanchez et al., 2008; Flowers and Colmer, 2015; Slama et al., 2015); (iii) controlling ion absorption, especially potassium $(\mathrm{K})$ ions, by roots and ion transfer to leaves. Owing to their role in maintaining an osmotic balance, $\mathrm{K}^{+}$ions play an important role in closing and opening stomata and as co-factors for many enzymes; (iv) selective accumulation or removal of ions (Mahajan and Tuteja, 2005); (v) producing nitric oxide (NO) (Del Río, 2015); (vi) activating antioxidant enzymes and producing antioxidant compounds (Ozgur et al., 2013; Wang et al., 2013); (vii) producing polyamines (Takahashi and Kakehi, 2009); (viii) altering photosynthetic pathways (Stepien and Johnson, 2009; Uzilday et al., 2014); (ix) compartmentalizing ions at the cellular and whole-plant levels (Pang et al., 2010; Shabala and Mackay, 2011); and (x) regulating the expression of genes involved in plant salinity tolerance. In terms of gene regulation, halophytic plants respond to salt stress by up-regulating a large number of genes and transcription factors (Kawasaki et al., 2001; Lim et al., 2010; Gupta and Huang, 2014; Kumari et al., 2015), and these can be grouped into the following functional categories: (i) senescence-associated genes (e.g., SAG); (ii) ion transport or homeostasis genes (e.g., SOS genes, AtNHX1, and $\mathrm{H}^{+}$-ATPase); (iii) molecular chaperones (e.g., HSP genes); and (iv) dehydration-related transcription factors (e.g., DREB) (Gupta and Huang, 2014).

Interest in salinity tolerant and halophytic plants is because of a trend toward increasing salinity in agricultural soils in the arid and semi-arid regions of the world. The potential use of halophytes and other salt-tolerant species would allow the production of crops in these areas. Halophytes have many potential uses (Figure 1; Gago et al., 2011; Manousaki and Kalogerakis, 2011; Ksouri et al., 2012; Rozema and Schat, 2013; Hasanuzzaman et al., 2014; Song and Wang, 2014; Cheeseman, 2015; Jesus et al., 2015; Akinshina et al., 2016; Himabindu et al., 2016), including their use as a reservoir for isolating halotolerant PGPRs.

\section{HALOTOLERANT PGPRs}

Eukaryotic and prokaryotic micro-organisms, including fungi, bacteria, and archaea, are able to adapt to a range of changes in external osmolarity (Ruppel et al., 2013). Halotolerant bacteria are able to grow in environments with a wide range of salinities, from 1 to $33 \% \mathrm{NaCl}$, as well as in the absence of $\mathrm{NaCl}$ (Larsen, 1986; Khan et al., 2016). They are therefore well-suited to grow in the rhizosphere of halophytes where there are often low water potentials due to salt stress in dry climates (Upadhyay et al., 2009; Ruppel et al., 2013). Interestingly, PGPRs isolated from environmental extremes maintain their PGP traits even in the presence of high salt concentrations. For example, Zhu et al. (2011) isolated a high phosphorus-solubilizing halotolerant PGPR, Kushneria sp. YCWA18, from the sediment of Daqiao saltern on the eastern coast of China that was able to grow on a solid medium containing $20 \%(\mathrm{w} / \mathrm{v})$ of sodium chloride. Tiwari et al. (2011) also isolated PGPRs that were halotolerant based on their ability to tolerate $2-25 \% \mathrm{NaCl}$; these included Bacillus pumilus, Pseudomonas mendocina, Arthrobacter sp., Halomonas sp., and Nitrinicola lacisaponensis with plant growthpromoting traits like phosphorus (P) solubilization and the ability to produce IAA, siderophores, and 1-aminocyclopropane1-carboxylate (ACC) deaminase. These are considered PGP traits due to their ability to provide $\mathrm{P}$ to the plant under $\mathrm{P}$ limiting conditions, promote plant growth by functioning as a phytohormone (IAA), provide Fe to the plant via chelation and uptake (siderophores), and deplete a precursor to the plant stress hormone ethylene (ACC deaminase). Distinct genera of halotolerant bacteria have been isolated from distinct halophytic plants such as Rosa rugosa (Bibi et al., 2011), Salicornia bigelovii (Rueda-Puente et al., 2010), Salicornia brachiate (Jha et al., 2012), Halocnemum strobilaceum (Al-Mailem et al., 2010), Acacia spp. (Boukhatem et al., 2012), Sesuvium portulacastrum (Bian et al., 2011; Anburaj et al., 2012), and Avicennia marina (El-Tarabily and Youssef, 2010), and from a wide range of habitats such as extreme alkali-saline soils, desert soils, and saline soils (Antón et al., 2002; Ventosa et al., 2008; Abou-Elela et al., 2010; Shi et al., 2012; Zhou et al., 2012; Ruppel et al., 2013). Many of these halotolerant bacteria exhibited an ability to promote plant growth (Table 1).

Halotolerant bacteria employ a range of strategies to grow and survive in saline habitats (Etesami and Beattie, 2017). These strategies include (i) minimizing the uptake of salt due to compositional properties of the cell membrane or cell wall; (ii) regulating intracellular ion concentrations by pumping ions out of the cell through electrogenic $\mathrm{Na}^{+} / \mathrm{H}^{+}$antiporters and $\mathrm{K}^{+} / \mathrm{Na}^{+}$ ion transporters for osmotic adjustment; (iii) accumulating compatible solutes such as sucrose, trehalose, glycosyl glycerol, 


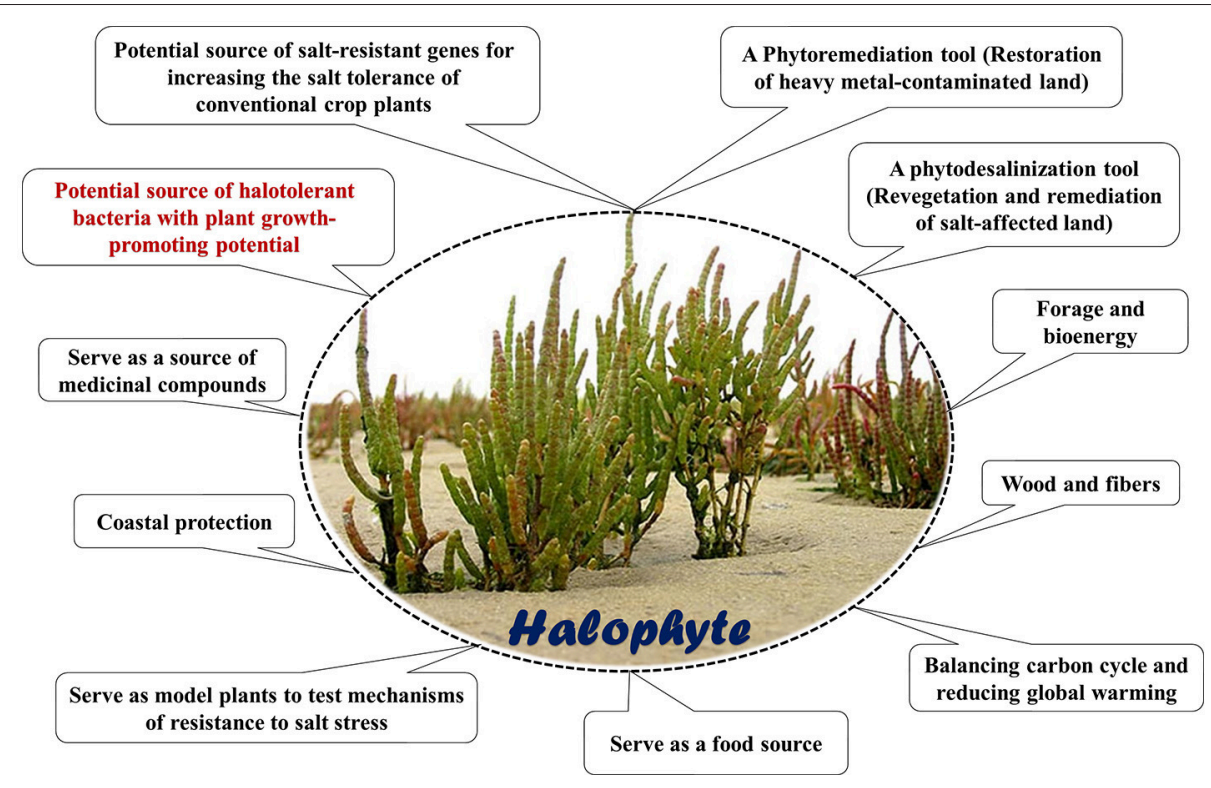

FIGURE 1 | Some potential use of halophytes

and glycine betaine by endogenous biosynthesis; (iv) producing proteins and enzymes that are adapted to high concentrations of solute ions; (v) increasing the energetic capacity; and (vi) producing exopolysaccharides (EPS) that help the development of hydrating biofilms (Sandhya et al., 2010; Ruppel et al., 2013; Qin et al., 2016). In addition to these strategies, fundamental cellular properties of halophytes may enhance their halotolerance, including their high GC content and a high proportion of proteins that exhibit a low hydrophobicity, a low tendency to form helices, and a high tendency to form stabilizing coil structures (Jacob, 2012; Szymańska, et al., 2016).

Several reports have shown that halotolerant PGPRs effectively improve growth of various agricultural crops under salinity stress conditions (Figure 2; Mayak et al., 2004a; Nabti et al., 2010; Shukla et al., 2012; Goswami et al., 2014; Ji et al., 2014; Kim et al., 2014; Kaushal and Wani, 2016; Orhan, 2016; Qin et al., 2016; Singh and Jha, 2016; Etesami, 2018). Mechanisms by which they improve growth have been predicted or shown to include (i) activating plant antioxidant defense machinery by upregulating the activity of key enzymes such as superoxide dismutase (SOD), peroxidase, and catalase (CAT) that scavenge excess reactive oxygen species (ROS), and protect the plants from salt toxicity (Jha and Subramanian, 2014; Islam et al., 2016; Qin et al., 2016); (ii) improving plant nutrition by fixing atmospheric nitrogen $\left(\mathrm{N}_{2}\right)$, solubilizing $\mathrm{P}$ or $\mathrm{K}$, producing siderophores for Fe uptake (Dodd and Pérez-Alfocea, 2012; Etesami and Beattie, 2017; Etesami, 2018); (iii) increasing the efficiency of inoculated plants to take up select ions for maintaining a high $\mathrm{K}^{+} / \mathrm{Na}^{+}$ ratio; this can directly reduce the accumulation of toxic ions such as $\mathrm{Na}^{+}$and $\mathrm{Cl}^{-}$and improve the nutritional status of both macronutrients and micronutrients by regulating ion transporter expression and/or activity (Giri et al., 2007; Zuccarini and Okurowska, 2008; Shukla et al., 2012; Islam et al., 2016; Etesami,
2018); (iv) decreasing plant $\mathrm{Na}^{+}$accumulation by excreting EPS to bind cations (especially $\mathrm{Na}^{+}$) in roots and prevent their translocation to leaves; this helps promote a physical barrier called a rhizosheath around the roots (Ashraf et al., 2004; Dodd and Pérez-Alfocea, 2012; Qin et al., 2016; Etesami and Beattie, 2017). EPS-producing-halotolerant PGPRs enhance the soil structure by promoting soil aggregation, which results in water retention and increased provision of nutrients to plants. EPS can also alleviate plant salt stress by binding $\mathrm{Na}^{+}$; this binding is due to the hydroxyl, sulfhydryl, carboxyl and phosphoryl functional groups characteristic of bacterial EPS (Watanabe et al., 2003; Nunkaew et al., 2015). Aeromonas hydrophila/caviae, Bacillus sp., Planococcus rifietoensis, Halomonas variabilis, Burkholderia, Enterobacter, Microbacterium, and Paenibacillus are some of the halotolerant PGPRs that produce EPS and facilitate biofilm formation (Upadhyay et al., 2011; Qurashi and Sabri, 2012; Ruppel et al., 2013; Khan et al., 2016); (v) synthesizing the enzyme ACC deaminase, which converts the plant ethylene precursor ACC to ammonia and $\alpha$-ketobutyrate (Etesami and Beattie, 2017), thus reducing the accumulation of ethylene in the plant and avoiding ethylene-mediated growth inhibition in response to abiotic stresses such as salinity (Etesami et al., 2014; Glick, 2014; Singh et al., 2015); (vi) changing root architecture and morphology, hydraulic conductance, and hormone status (Arora et al., 2006, 2012). These root changes, which may result from increased IAA, can facilitate the uptake of more nutrients and provide access to a more extensive network of soil water (Vacheron et al., 2013; Goswami et al., 2014); (vii) emitting stress-related volatile compounds that enhance plant biomass and survival under severe drought stress (Timmusk et al., 2014); (viii) accumulating osmolytes such as amino acids and their derivatives (e.g., glutamate, proline, peptides, and $\mathrm{N}$-acetylated amino acids), quaternary amines (e.g., glycine 


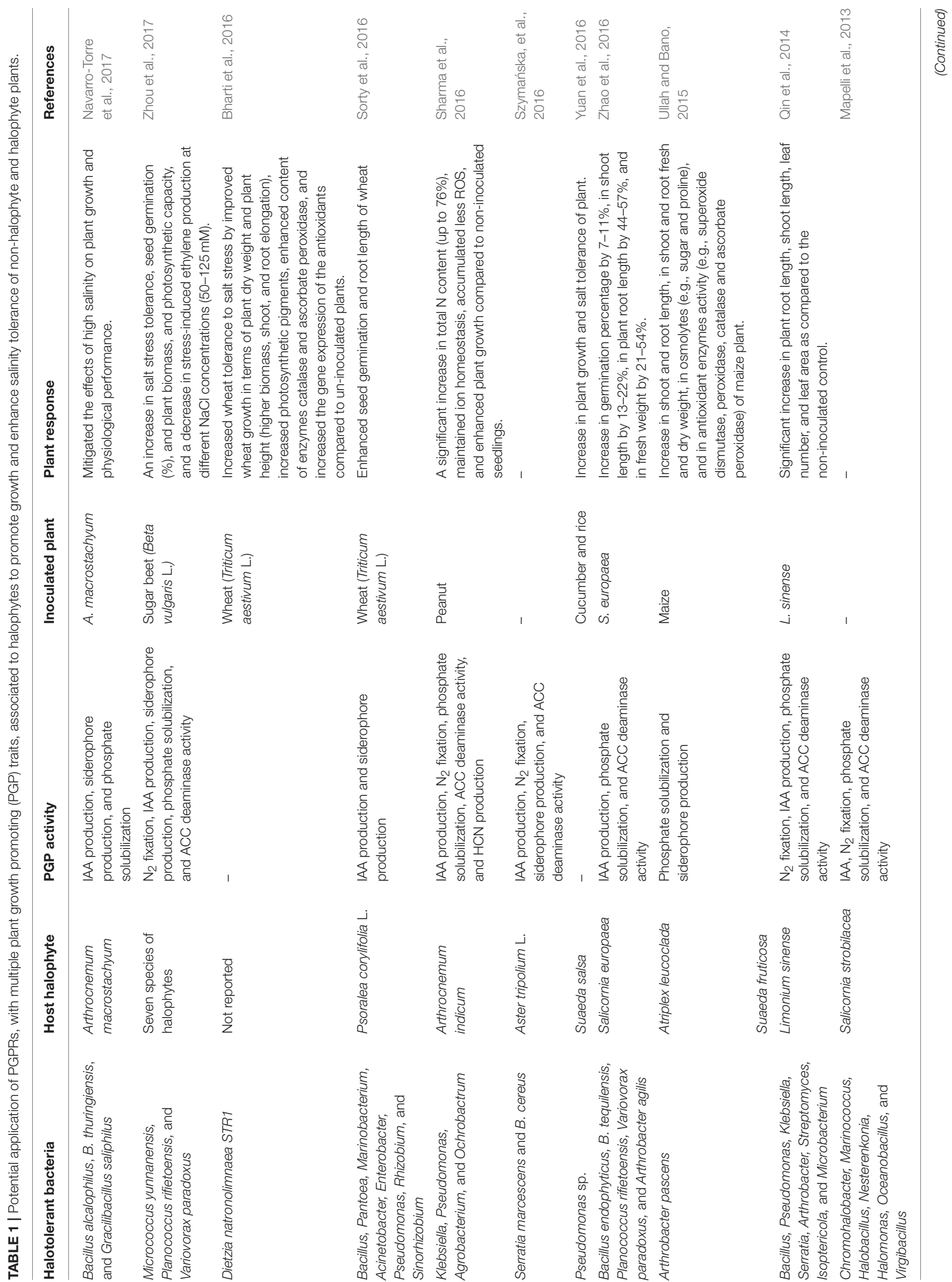




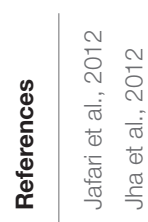

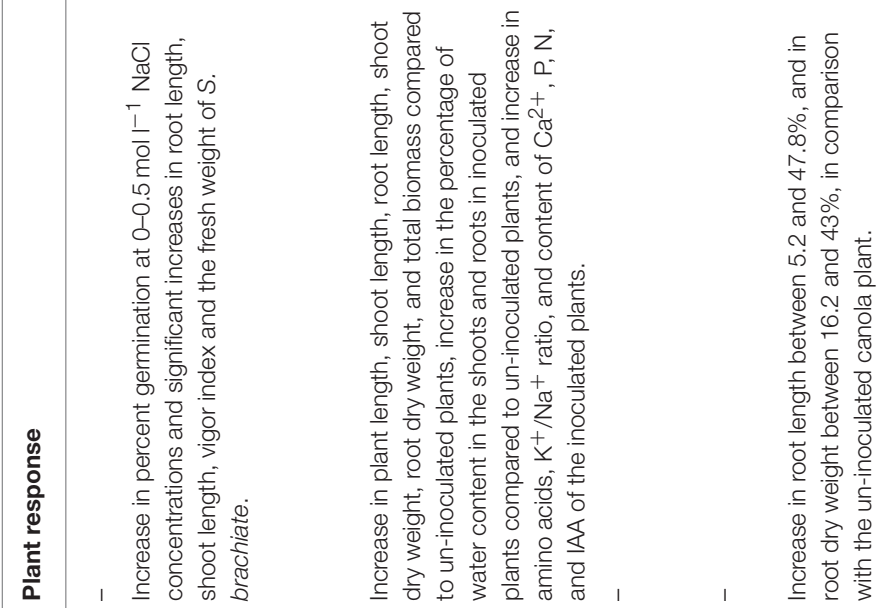

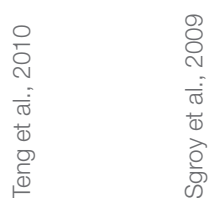

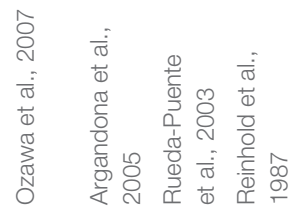

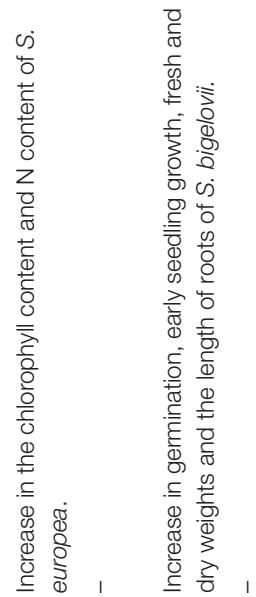

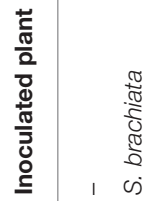

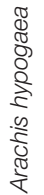<smiles>[CH][CH]</smiles>

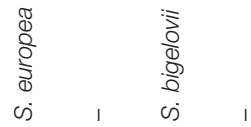

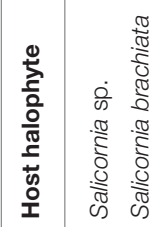
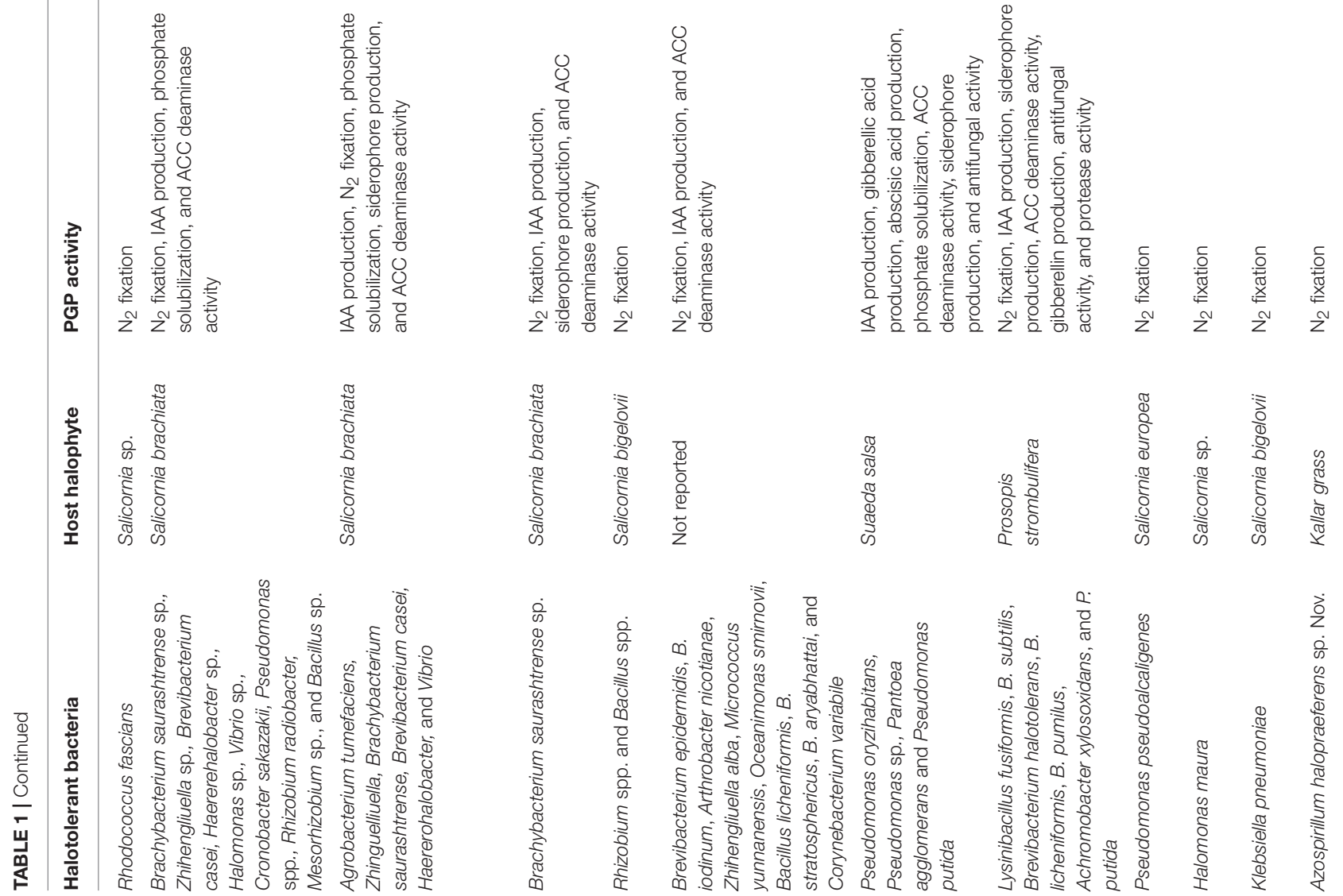


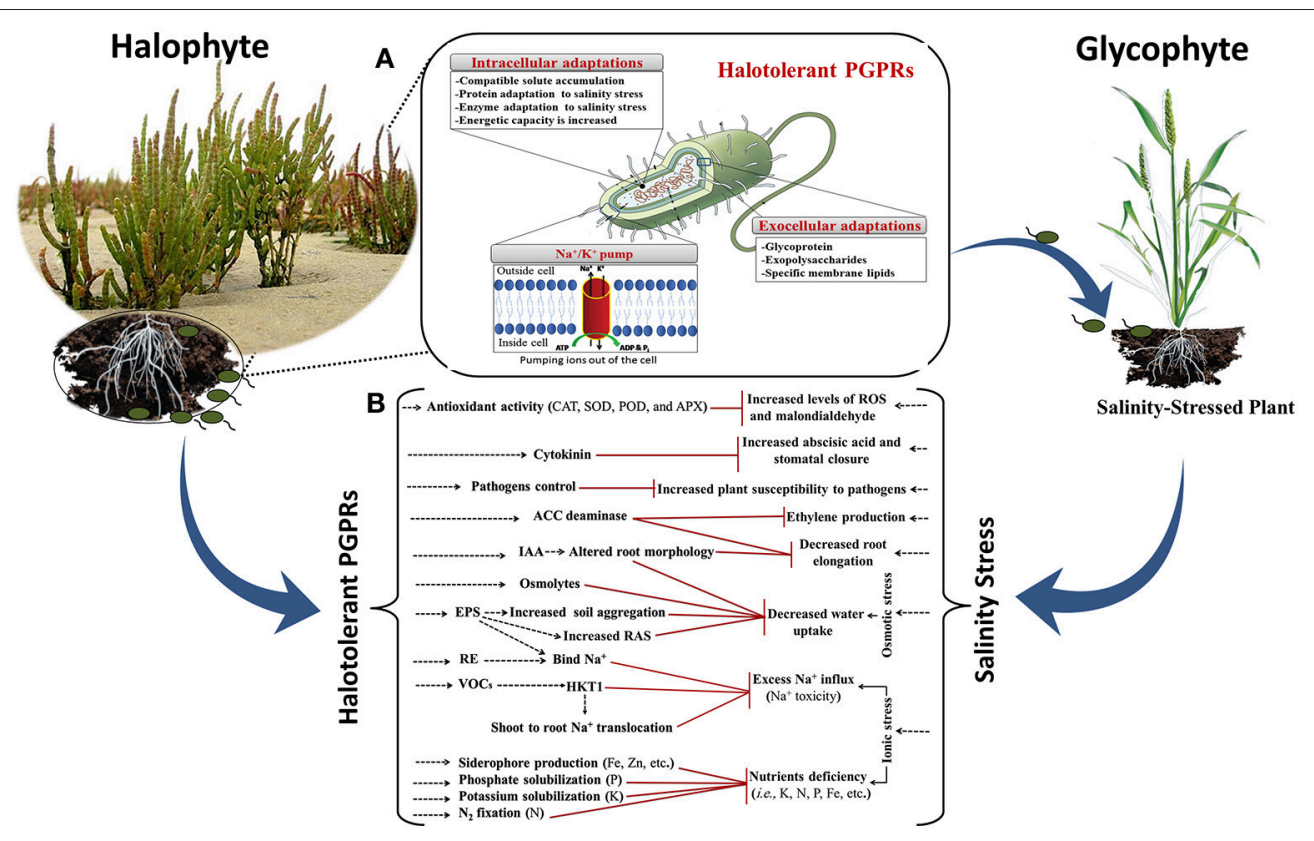

FIGURE 2 | (A) Schematic overview of the mechanisms developed by halotolerant plant growth promoting rhizobacteria (PGPRs) to live and survive in highly salinity conditions. For more details, see this reference (Ruppel et al., 2013). (B), Beneficial attributes of halotolerant PGPRs toward salinity stress tolerance in non-halophyte crops grown in saline soils. Red arrows indicate rhizobacterial components negating salinity stress effects. Halotolerant PGPRs increase the $\mathrm{K}^{+} / \mathrm{Na}^{+}$ratio by selectively enhancing $\mathrm{K}^{+}$uptake and avoiding translocation of toxic $\mathrm{Na}^{+}$under saline conditions. These bacteria are capable of increasing the antioxidative systems in plants for reactive oxygen species (ROS) scavenging such as enzymatic components of superoxide dismutase (SOD), catalase (CAT), ascorbate peroxidase (APX), peroxidase (POD), and glutathione reductase (GR) and non-enzymatic components of cysteine, glutathione and ascorbicacid. 1-aminocyclopropane-1-carboxylate (ACC)-deaminase producing PGPRs decrease the excessive ethylene production in plants caused by salinity stress and thereby eliminate the negative effect of ethylene on roots. Production of phytohormones increases the overall growth and also alters root characteristics (i.e., alteration of root proliferation, metabolism and respiration rate) to facilitate uptake of water and nutrients. Phytohormone indole-3-acetic acid (IAA) also increases the size of aerial parts of the plants. Production of osmoprotectants (i.e., proline, polyamines, glutamate, total free amino acids, etc.) by PGPR also contributes to salinity stress tolerance in PGPRs-inoculated plants. Exopolysaccharides (EPS) bind the toxic $\mathrm{Na}^{+}$and restrict $\mathrm{Na}^{+}$influx into roots. Soil aggregation due to production of EPS or alteration of root exudates (RE) hydrates the rhizosphere and helps in enhancing uptake of water and nutrients. EPS also increase root adhering-soil (RAS). Volatile organic compounds (VOCs) can trigger induction of high affinity $\mathrm{K}^{+}$transporter (HKT1) in shoots and reduction of $\mathrm{HKT} 1$ in roots, limiting $\mathrm{Na}^{+}$entry into roots and facilitating shoot-to-root $\mathrm{Na}^{+}$recirculation. For more details, see these references (Dutta and Khurana, 2015; Kaushal and Wani, 2016; Qin et al., 2016; Sáenz-Mata et al., 2016).

betaine and carnitine), and sugars (e.g., sucrose and trehalose) (Creus et al., 2004); (ix) preserving higher stomatal conductance and photosynthetic activities (del Amor and Cuadra-Crespo, 2012), which can reduce the accumulation of toxic ions $\left(\mathrm{Na}^{+}\right.$and $\mathrm{Cl}^{-}$) and improve the ratio of $\mathrm{K}^{+}: \mathrm{Na}^{+}$in the leaf (Pérez-Alfocea et al., 2010); (x) inducing the expression of stress-responsive genes. In particular, halotolerant PGPRs cause up-regulation of stress tolerance genes (Kaushal and Wani, 2016; Etesami and Beattie, 2017) such as RAB18 (LEA), the RD29A and RD29B regulons of ABA-responsive elements $(A B R E)$, and dehydration responsive elements $(D R E)$, as well as the transcription factor DREB2b DRE binding protein. They also can induce genes that encode proteins related to energy metabolism and cell division, particularly amino acid metabolism and the tricarboxylic acid cycle (Banaei-Asl et al., 2015; Qin et al., 2016). The halotolerant PGPRs Azospirillum brasilense, Pantoea agglomerans, and Bacillus megaterium can help plants decrease their cellular water potential by increasing the expression of genes PIP2, ZmPIP1-1, and $H v P I P 2-1$, which are involved in producing aquaporins. Aquaporins are water channel proteins in the plasma membranes of plant cells that contribute to the transfer of water into the plant
(Marulanda et al., 2010; Zawoznik et al., 2011; Gond et al., 2015; Moshelion et al., 2015). PGPRs induction of aquaporins may encourage plants to continue to take up water from salt-affected soils (Qin et al., 2016). Furthermore, the PGPR B. subtilis can also decrease the absorption of excessive amounts of $\mathrm{Na}^{+}$by the roots of plants by down-regulating expression of the highaffinity $\mathrm{K}^{+}$transporter (HKT1) in the roots of salinity-affected plants (Zhang et al., 2008; Qin et al., 2016). In addition, these halotolerant PGPRs facilitate shoot-to-root $\mathrm{Na}^{+}$recirculation by triggering the induction of HKT1 in shoots (Zhang et al., 2008); and (xi) protecting plants from phytopathogens, such as by producing extracellular enzymes to hydrolyze fungal cell walls, synthesizing antimicrobial compounds, producing Fe-chelating siderophores to starve phytopathogens for $\mathrm{Fe}$, excluding pathogens via competition for nutrients and sites on root, and inducing systemic resistance (Glick and Bashan, 1997; Bhattacharyya and Jha, 2012; Etesami, 2018).

Inoculating crops with halotolerant PGPRs isolated from halophytes has been successful at improving crop growth and tolerance under salt stress conditions (Shukla et al., 2012; Khan et al., 2016). Halotolerant PGPRs can provide many benefits to 
plants, including helping halophytes and glycophytes overcome salt stress (Table 1). For example, salt- tolerant PGPRs isolated from rhizospheric soil of the halophytes Haloxylon salicornicum, Lespedeza bicolor, Atriplex leucoclada, Suaeda fruticosa, and Salicornica virginica also enhanced the growth of salinitystressed maize (Ullah and Bano, 2015). These plants exhibited an accumulation of osmolytes (e.g., sugar and proline) and increase in antioxidant enzyme activity (e.g., SOD, peroxidase, CAT, and ascorbate peroxidase) as compared to un-inoculated plants. Similarly, a study by Siddikee et al. (2010) showed that, following the inoculation of canola seedlings with halotolerant bacterial isolates isolated from halophytic plants under salt stress in gnotobiotic conditions, the plants exhibited significantly increased growth, as shown by a 35-43\% increase in dry weight and $29-47 \%$ increase in root length. The studies shown in Table 1 illustrate that PGPRs isolated from the rhizosphere of halophytic species can be used as effective bio-inoculants for non-halophytic crops grown under salt stress.

\section{Halophytes and ACC \\ Deaminase-Producing PGPRs}

Ethylene is a plant growth regulator and stress hormone (Mayak et al., 2004b; Pierik et al., 2007) that is produced by almost all plant species. This gaseous growth hormone has a key role in causing physiological changes in plants at the molecular level. The production of ethylene is significantly enhanced in response to environmental stresses such as drought and salinity. Excessive ethylene inhibits root growth and, as a consequence, limits further growth of the plant. High ethylene levels in nodules is also associated with decreased $\mathrm{N}_{2}$ fixation (Ma et al., 2002). Although ethylene production near roots is constantly modulated during plant growth and development (Mayak et al., 2004a; Mahajan and Tuteja, 2005; Gamalero and Glick, 2015), reducing stress-induced ethylene levels alleviates some effects of stress on plants (Glick, 2004; Etesami and Beattie, 2017).

As described earlier, PGPRs that secrete the enzyme ACC deaminase can reduce ethylene levels by metabolizing ACC, a precursor of plant-produced ethylene, into $\alpha$-ketobutyrate and ammonia (Etesami and Beattie, 2017). Plants inoculated with ACC deaminase-producing PGPRs often exhibit extended root growth, attributed to reductions in ethylene, and enhanced resistance to salinity stress (Mayak et al., 2004a,b; Cheng et al., 2007; Glick et al., 2007; Zahir et al., 2009; Nadeem et al., 2010; Barnawal et al., 2012; Jha et al., 2012; Etesami and Beattie, 2017). These PGPRs can also influence plant ethylene homeostasis by altering the expression of genes encoding the ethylene synthesis enzymes ACC synthase and ACC oxidase (Tsukanova et al., 2017).

Although salinity has been associated with the loss in ACC deaminase production by some PGPRs (Upadhyay et al., 2009), at least some salt-tolerant PGPRs isolated from saline environments appear to maintain ACC deaminase production based on documentation of their beneficial properties in helping plants overcome salinity stress by reducing ethylene levels (Mayak et al., 2004a). For example, 25 out of 140 halotolerant bacterial isolates from coastal soils of the South Korean Yellow Sea showed ACC deaminase activity (Siddikee et al., 2010); these bacterial isolates belonged to the genera of Arthrobacter, Bacillus, Brevibacterium, Corynebacterium, Exiguobacterium, Halomonas, Micrococcus, Oceanimonas, Planococcus, and Zhihengliuella. ACC deaminaseproducing PGPRs isolated from saline environments alleviated salinity stress in a variety of plants. For example, the ACC deaminase-producing PGPR strains $P$. fluorescens N3 and $P$. putida Q7 promoted the growth of maize roots by 3.3-fold, and maize shoots by 2.3 -fold, respectively, under salinity stress as compared to un-inoculated controls (Kausar and Shahzad, 2006; Khan et al., 2016). Similarly, inoculation of legume plants with ACC deaminase-producing rhizobia isolated from saline soils promoted nodule formation (Shaharoona et al., 2006), and inoculation of wheat plants with the PGPR strain A. brasilense FP2 from saline soils resulted in a decrease in the expression of the plant ACC oxidase (Camilios-Neto et al., 2014).

In addition to halotolerant bacteria isolated from saline environments, halotolerant bacteria isolated from various halophytic species exhibit ACC deaminase production (Table 1; Siddikee et al., 2010; Jha et al., 2012; Zhou et al., 2017). ACC deaminase-producing PGPRs isolated from halophytes have been found to alleviate salinity stress and increase plant growth for both halophytes and salinity-sensitive crop plants (Table 1). For example, novel diazotrophic halotolerant bacteria isolated from the roots of Salicornia brachiata featured ACC deaminase activity and these isolates included Brachybacterium saurashtrense, Brevibacteriumcasei, Cronobacter sakazakii, Haererehalobacter, Halomonas, Mesorhizobium, Pseudomonas, Rhizobium radiobacter, Vibrio, and Zhihengliuella (Jha et al., 2012). Moreover, growth parameters of S. brachiate increased significantly under salt stress after re-inoculation with $B$. saurashtrense and Pseudomonas (Jha et al., 2012). In another study (El-Tarabily and Youssef, 2010), one out of 62 bacterial isolates from the A. marina rhizosphere exhibited a high level of ACC deaminase activity. Following inoculation of this isolate, identified as $P$. maricaloris, plant seedlings exhibited a decrease in the endogenous levels of ACC and improved growth undersalinity stress. Following the inoculation of red pepper plants with the ACC deaminase-producing halotolerant PGPRs Brevibacterium iodinum, Zhihengliuela alba, and Bacillus licheniformis isolated from halophytes, ethylene levels in the plants decreased by 44,53, and 57\%, respectively. Furthermore, their salt tolerance, as assessed using a salt tolerance index, increased significantly compared to non-inoculated plants (Siddikee et al., 2011). These studies illustrate that habitatadapted ACC deaminase-producing PGPRs associated with halophytes can mitigate the effects of salinity stress on crops and reduce ethylene to below growth-inhibitory levels (Jha et al., 2012).

Considerable attention has been given to the isolation of ACC deaminase-producing salt-tolerant PGPRs for their use in promoting plant growth in saline environments (Hardoim et al., 2008; Nadeem et al., 2010; Ali et al., 2014). Methods of isolating such PGPRs are well-established (Penrose and Glick, 2003). A rapid and efficient approach to their isolation is using polymerase chain reaction (PCR)-based screening for the ACC deaminase-encoding gene acdS coupled to a colorimetric 
ninhydrin assay to measure ACC (Nikolic et al., 2011; Jasim et al., 2015; Li et al., 2015b; Qin et al., 2016). Interestingly, recent results suggest that endophytic bacteria are more able to produce the enzyme ACC deaminase than PGPRs isolated from other habitats, including the surfaces of leaves and roots and from non-rhizosphere soil (Bruto et al., 2014; Qin et al., 2016). Future research that compares the bio-activity of ACC deaminase-producing bacteria isolated from various habitats, including distinct tissues of halophytic plants, would be useful.

\section{Halophytes and Phytohormone-Producing PGPRs}

Phytohormones regulate the protective response of plants to biotic and abiotic stresses (Raghavan et al., 2006), and also the development and tolerance to diverse environmental stresses including salinity stress (Ryu and Cho, 2015). Plant responses to salt stress include an array of changes at the molecular, biochemical, and physiological levels (Manchanda and Garg, 2008; Ahmad et al., 2013; Kumari et al., 2015), and depend upon environmental conditions, soil properties, and plant growth stage (Zhu et al., 1992). Previous studies (Dodd and PérezAlfocea, 2012; Khan et al., 2016) indicate that salinity can either diminish $(300 \mathrm{mM} \mathrm{NaCl})$ (Dunlap and Binzel, 1996) or increase (100 mM NaCl) (Albacete et al., 2008) endogenous IAA levels in roots. Plants can also respond to exogenous phytohormones, and these can relieve the adverse effects of salinity (Singh and Jain, 1982; Zahir et al., 2010). Thus, exogenous application of phytohormones and their precursors provides an attractive approach to counter salt stress conditions by changing the balance of endogenous levels of hormones (Ilangumaran and Smith, 2017). This was illustrated in a study showing that treating wheat seeds with IAA reduced the detrimental effects of salinity stress on wheat growth (Datta et al., 1997). In addition to stimulating root proliferation, which can enhance growth and salt tolerance (Dodd and Pérez-Alfocea, 2012), IAA can help maintain leaf growth, which helps prevent salinity-induced limitations in plant productivity (Munns, 2002; Albacete et al., 2008). IAA has also been reported to enhance the protection of bacterial cells against abiotic stresses such as high salt concentrations (Bianco et al., 2006).

PGPRs may enhance plant growth, in part, by modulating the plant hormonal balance (Ilangumaran and Smith, 2017; Tsukanova et al., 2017). IAA production is a relatively common trait of most salt-tolerant PGPRs (Dodd et al., 2010), and IAAproducing PGPRs can increase the fitness of plants grown in salt-affected soils (Tiwari et al., 2011). PGPRs may improve crop salt tolerance by altering hormonal root-shoot signaling (Yang et al., 2009). The ability to modify plant stress levels by providing IAA, which influences the development of lateral roots, has previously been reported for halotolerant-bacteria isolated from coastal soils (Siddikee et al., 2010), halophyte roots in Argentina (Sgroy et al., 2009), highly saline habitats (Tiwari et al., 2011), the halophyte Prosopis strombulifera (Piccoli et al., 2011), the rhizosphere of halophytic weeds from the Pakistani Khewra salt range (Naz et al., 2009), halotolerant plants from a Chinese coastal sandbank (Bian et al., 2011), and the rhizosphere of
C. annum growing in desert areas (Marasco et al., 2012). Some IAA-producing salt-tolerant PGPRs isolated from halophytes are shown in Table 1, as is their potential as a tool for promoting the salt tolerance of halophytes and glycophytes. For example, Tiwari et al. (2011) demonstrated that inoculation of wheat with IAA-producing salt-tolerant Halomonas sp. resulted in a higher IAA content in the rhizosphere of treated plants than control plants and increased plant growth. In another study, the IAA-overproducing strain Sinorhizobium meliloti ameliorated the reduced growth of Medicago truncatula in saline soils (Bianco and Defez, 2009). This work was further supported by Egamberdieva (2009). These studies clearly show that managing IAA production in halophytic and non-halophytic plants by endophytic and rhizosphere bacteria may be an important tool in conferring salt tolerance.

Cytokinins (CKs) are also involved in the development of plant resistance to biotic and abiotic stresses (Großkinsky et al., 2011; O’Brien and Benková, 2013). CK production is a relatively common trait of PGPRs (Dodd et al., 2010). PGPRs can influence plant $\mathrm{CK}$ concentration by synthesizing $\mathrm{CK}$ or altering CK homeostasis in the plant (Arshad and Frankenberger, 1991; de Garcia Salamone et al., 2005; Glick, 2012; Pallai et al., 2012; Kapoor and Kaur, 2016). The Platycladus orientalis plants inoculated with a CK-producing PGPR strain B. subtilis had increased CK levels in the shoots and were more resistant to drought (Liu et al., 2013). Increased growth of drought-stressed lettuce plants inoculated with a CK-producing B. subtilis strain suggested modulation of root-to-shoot CK signaling (Arkhipova et al., 2007). The ability of PGPRs to synthesize CK or alter plant CK homeostasis highlights the importance of understanding how PGPRs stimulate growth and increase plant resistance to salinity.

Gibberellic acid (GA) positively regulates cell division and elongation, hypocotyl and stem growth, and leaf and root meristem size (Guo et al., 2015; Wang et al., 2015; Martínez et al., 2016). GA signaling is a key factor in the inhibition of plant growth under stress (Magome and Kamiya, 2016; Martínez et al., 2016). PGPRs can influence the endogenous GA levels in plants (Bottini et al., 2004; Kang et al., 2014a; Shahzad et al., 2016). Some PGPR strains, such as B. amyloliquefaciens RWL-1, Promicromonospora sp. SE188, Leifsonia soli SE134, and Enterococcus faecium LKE12, can synthesize GA (Bottini et al., 2004; Kang et al., 2012, 2014a; Lee et al., 2015; Shahzad et al., 2016). After inoculation of plants with the GA-producing PGPR strains, B. cereus MJ-1 (Joo et al., 2005) and Promicromonospora sp. SE188, the amount of endogenous GA in the shoots increased (Kang et al., 2014a). Some bacterial isolates from the halophyte P. strombulifera (Piccoli et al., 2011) and the rhizosphere of halophytic weeds from the Pakistani Khewra salt range showed the ability to produce GA (Naz et al., 2009), as did the PGPR strains B. licheniformis, Lysinibacillus fusiformis, Achromobacter xylosoxidans, and Brevibacterium halotolerans isolated from the halophyte P. strombulifera (Sgroy et al., 2009).

Abscisic acid (ABA) is an important plant stress hormone that is synthesized in response to abiotic stresses and activates the genes responsible for stress resistance (Sah et al., 2016). This hormone plays an important role in alleviating salinity stress by mediating stomatal, and thereby photosynthetic, responses 
to high salinity (Dodd and Pérez-Alfocea, 2012). It also plays a crucial role in plant-PGPR interactions (Dodd, 2003). Many PGPRs produce ABA in vitro (Dodd et al., 2010); these include $A$. brasilense, B. licheniformis, Novosphingobium sp., P. fluorescens, Rhodococcus sp. P1Y, and Variovorax paradoxus (Sgroy et al., 2009; Jiang et al., 2012; Belimov et al., 2014; Salomon et al., 2014; Cohen et al., 2015). PGPRs can also produce ABA under salinity stress conditions and increase growth of salinized plants (Naz et al., 2009). For example, in a study, following inoculation of plants with ABA-producing strains such as $B$. licheniformis Rt4M10, P. fluorescens Rt6M10, A. brasilense Sp 245, the internal ABA content increased and inoculated plants become more resistant to drought compared to un-inoculated plants (Salomon et al., 2014; Cohen et al., 2015). In addition, inoculation with ABA-producing PGPRs often decreased the accumulation and concentration of $\mathrm{ABA}$ in roots and significantly altered the longdistance signaling of shoot-to-root ABA transport in the phloem and the root-to-shoot ABA transport in the xylem (Dodd and Pérez-Alfocea, 2012; Jiang et al., 2012; Belimov et al., 2014; Qin et al., 2016); the resulting changes in ABA levels may mitigate the plant's sensitivity to water scarcity. Recently, the two rhizospheric bacteria Rhodococcus sp. and Novosphingobium sp. were found to metabolize ABA in vitro (Belimov et al., 2014; Qin et al., 2016), suggesting a mechanism for decreasing plant ABA concentrations. Interestingly, disrupting plant ABA homeostasis can influence the activity of halotolerant PGPRs, as shown by wild-type tomato plants that exhibited enhanced growth, and ABA-deficient mutant plants that exhibited reduced growth, in response to B. megaterium inoculation (Porcel et al., 2014; Qin et al., 2016). Collectively, these results suggest that ABAproducing halotolerant PGPRs, ABA-metabolizing halotolerant PGPRs, and general halotolerant PGPRs will act differently in adjusting plant ABA status and thus may result in variable plant responses to salinity stress. ABA production has also been reported in bacterial isolates from halophytes, including from the rhizosphere of halophytic weeds from the salt range of Pakistani Khewra (Naz et al., 2009) and the halophyte P. strombulifera (Piccoli et al., 2011). L. fusiformis, B. subtilis, B. halotolerans, B. licheniformis, B. pumilus, A. xylosoxidans, and Pseudomonas putida are some ABA-producing bacteria isolated from the halophyte $P$. strombulifera (Sgroy et al., 2009). Relatively little is known of the role of ABA in plant-bacterial interactions. The ability of PGPRs to alter ABA levels in plants suggest opportunities to use these bacteria to influence plant growth and abiotic stress resistance, and highlights a need for more research to understand how PGPRs influence plant ABA signal transduction components.

Jasmonic acid (JA) is also involved in abiotic stress resistance (Ahmad et al., 2016). Several endophytic PGPRs synthesize JA and salicylic acid (SA) (Forchetti et al., 2007; Chen et al., 2014). Inoculating plants with the PGPR strains $P$. fluorescens Pf4, $P$. aeruginosa Pag (Singh et al., 2003), and B. amyloliquefaciens LJ02 (Li et al., 2015a) resulted in a rise in the endogenous levels of $\mathrm{SA}$ in various plant tissues. Inoculation of Vitis vinifera with the PGPR strain Burkholderia phytofirmans PsJN also led to SA accumulation (Bordiec et al., 2010), as did inoculation with the GA-producing PGPR strains Promicromonospora sp. SE188
(Kang et al., 2012) and B. amyloliquefaciens RWL-1 (Shahzad et al., 2016).

Although there is some evidence that PGPRs improved plant salt tolerance by altering the endogenous hormone status (Kang et al., 2014b; Sahoo et al., 2014; Qin et al., 2016; Ilangumaran and Smith, 2017), little is known about how PGPRs influence this process. We have a similar knowledge deficit regarding the potential for halotolerant PGPRs to synthesize many of these phytohormones and to produce them in vitro or in planta. Bacterial isolates from halophytes have thus far been screened primarily for IAA synthesis, among the hormones discussed. However, the roles of GA, ABA, CK, SA, and JA in the physiology of plant halotolerance indicates that future research on how bacterial isolates from halophytes influence phytohormone homeostasis in plants may be fruitful.

\section{Halophytes and Phosphate-Solubilizing PGPRs}

Phosphorus is one of the major essential macronutrients for plants. Although organic and inorganic $\mathrm{P}$ are abundant in soils, $\mathrm{P}$ availability is limited due to its presence in insoluble forms. Whereas, P comprises about $0.05 \%(\mathrm{w} / \mathrm{w})$ of soils, often only $0.1 \%$ of the total $\mathrm{P}$ is available to plants because of poor solubility and its fixation in soil (Goldstein, 1986). In both saline soil-based and fertile soil-based agriculture, intensive cultivation strongly depletes soil nutrients. The use of inorganic NPK fertilizers increases soil salinity, particularly when coupled with saline irrigation. Phosphate-solubilizing halotolerant PGPRs provide an opportunity to enhance $\mathrm{P}$ availability to plants without exacerbating soil salinity levels. Phosphate-solubilizing PGPRs can solubilize insoluble phosphates via various mechanisms like chelation, ion exchange, and acidification by secreting low molecular weight organic acids (Sharma et al., 2013; Etesami, 2018). In salt-affected soils, inoculation with phosphatesolubilizing halotolerant PGPRs improved plant growth and suppressed the adverse effects of salt (Giri et al., 2004). Following the inoculation of Solanum lycopersicum plants with Achromobacter piechaudii, plant $\mathrm{P}$ content and water use efficiency increased under salinity stress (Mayak et al., 2004a). Similarly, inoculation of wheat with $B$. aquimaris increased plant $\mathrm{P}$ content under salinity stress in the field (Upadhyay and Singh, 2015). Both studies suggest that phosphate-solubilizing PGPRs solubilize insoluble P in saline soils. Halotolerant bacteria isolated from halophytes also exhibit $\mathrm{P}$ solubilization activity (Table 1). A screen of the mangrove A. marina rhizosphere identified 129 bacterial strains with the ability to solubilize rock phosphate, with Oceanobacillus picturae able to mobilize $97 \%$ of this mineral (El-Tarabily and Youssef, 2010). Bacteria isolated from halophytes, including Arthrobacter, Bacillus, Azospirillum, Vibrio, Phyllobacterium, and O. picturae, were shown to solubilize $\mathrm{Ca}_{3}(\mathrm{PO} 4)_{2}, \mathrm{AlPO}_{4}$, and $\mathrm{FePO}_{4}$ (Bashan et al., 2000; Banerjee et al., 2010; El-Tarabily and Youssef, 2010; Yasmin and Bano, 2011) and increase the $P$ content in both halophytes and glycophytes under salinity stress (Table 1). When the halophytes $S$. bigelovii and S. bigelovii were inoculated with various halotolerant PGPRs, including Azospirillum, Vibrio, Bacillus, and 
Phyllobacterium, the P content of the foliage increased (Bashan et al., 2000). This increased $\mathrm{P}$ content in plant tissues may help ameliorate the growth-restraining effects of salinity.

\section{Halophytes and Siderophore-Producing PGPRs}

Iron is a micronutrient that is a component of many enzymes involved in biochemical processes, including respiration, photosynthesis, and $\mathrm{N}_{2}$ fixation (Kobayashi and Nishizawa, 2012; Abbas et al., 2015). Iron availability is very low in calcareous and saline sodic soils throughout the world (Rabhi et al., 2007; Abbas et al., 2015). These soils suppress the availability of most micronutrients, including iron, and suppress plant growth by concurrent salinity and iron deficiency stresses (Yousfi et al., 2007; Abbas et al., 2015). PGPRs often secrete siderophores, which are small, high-affinity $\mathrm{Fe}(\mathrm{III})$-chelating compounds that scavenge iron, and the iron-siderophore complexes can be easily accessed by plants (Kloepper et al., 1980). Siderophore production by halotolerant PGPRs isolated from halophytes has been reported (Table 1); however, the ability of these strains to increase the availability of iron and other micro-elements, such as $\mathrm{Zn}, \mathrm{Mn}$, and $\mathrm{Cu}$, to plants is not yet known.

\section{Halophytes and $\mathbf{N}_{\mathbf{2}}$-Fixing PGPRs}

Most agricultural systems depend on the application of exogenous nitrogen, as it is often the nutrient that most limits productivity (Vitousek and Howarth, 1991). The productivity of halophytic crop species can also be limited by a lack of available $\mathrm{N}$ in saline soils. For legumes, nitrogen fixation is more sensitive than plant growth to soil salinity (Djekoun and Planchon, 1991), and all stages in nodule formation and nodule function are negatively affected by salinity (de la Peña and Pueyo, 2012; Bruning and Rozema, 2013). Salinity can interfere with plant $\mathrm{N}$ nutrition and thus decrease the $\mathrm{N}$ content of plant tissues (Naidoo, 1987), as illustrated by salinity-mediated repression of ammonium and nitrate uptake and assimilation (Ullrich, 2002). Typically, farmers use chemical fertilizers to compensate for a lack of soil $\mathrm{N}$; however, the excessive use of inorganic fertilizers may increase salinity, severely degrade the soil structure, and change the composition of the soil microflora (Akhavan-Kharazian et al., 1991; Rueda-Puente et al., 2003). Salinity also results in low soil microbial activity due to osmotic stress and ion toxicity. Increases in soil salinity in many parts of the world are therefore limiting plant productivity and the benefits accrued from biological $\mathrm{N}_{2}$ fixation (Jha et al., 2012). Salt-tolerant $\mathrm{N}_{2}$-fixing PGPRs can tolerate osmotic stress by producing osmolytes that allow them to maintain their cell turgor and metabolism (Yan et al., 2015). $\mathrm{N}_{2}$ fixation by salt-tolerant bacteria associated with the roots of halophytes is an important source of available $\mathrm{N}$ in saline soils. Furthermore, these roots are a source of halotolerant $\mathrm{N}_{2}$-fixing bacteria with plant growthpromoting potential (Table 1; Rueda-Puente et al., 2003; Jha et al., 2012; Sharma et al., 2016), some of which have been found to increase the growth of halophytes as well as non-halophytic crops in saline soils (Table 1). The potential benefits of biological $\mathrm{N}_{2}$ fixers to halophytes and salt-sensitive crops (Rueda-Puente et al., 2003; Jha et al., 2012) highlight the interest in exploring $\mathrm{N}_{2}$-fixing halotolerant PGPRs as potential bio-fertilizer resources for saline soil-based agriculture.

\section{Halophytes and PGPRs That Control Phytopathogens}

In addition to disrupting plant physiology and morphology, soil salinity increases plant susceptibility to pathogens (Besri, 1993). Plant diseases are a major constraint to crop yields but can potentially be controlled biologically by using PGPRs. Biological control using PGPRs offers a more eco-friendly approach to disease management than agricultural chemicals (Compant et al., 2010; Etesami and Alikhani, 2018). Some mechanisms that PGPRs use to counter the deleterious effects of phytopathogens include (Olanrewaju et al., 2017): (i) the synthesis of one or more antimicrobial metabolites (Couillerot et al., 2009), many of which have been reported in PGPRs of the genera Bacillus and Pseudomonas. These metabolites may serve as cytotoxic, antifungal, antibacterial, phytotoxic, antihelminthic, antiviral, antioxidant, and/or antitumor agents (Olanrewaju et al., 2017); (ii) the production of fungal cell wall-degrading enzymes (Chernin et al., 1995) such as lipase, which can degrade some fungal cell wall-associated lipids, $\beta-1,3$ glucanase, which can degrade cell wall carbohydrates, chitinase, which can degrade the integral fungal cell wall component chitin (Husson et al., 2017), and protease, which can degrade cell wall proteins (Vaddepalli et al., 2017); (iii) competition either for nutrients or for binding sites on plant roots (Barahona et al., 2011); such competition can limit phytopathogen growth or binding to the plant thereby making it difficult for the pathogen to proliferate (Olanrewaju et al., 2017); (iv) the synthesis of hydrogen cyanide, which when produced by bio-control PGPRs such as Rhizobium, Pseudomonas, Alcaligenes, Bacillus, and Aeromonas, inhibits cytochrome $\mathrm{C}$ oxidase as well as other important metalloenzymes (Nandi et al., 2017); (v) activation of induced systemic resistance, which is a resistance mechanism in plants (Van Loon et al., 1998; Halfeld-Vieira et al., 2006) in which exposure of plants to specific microbes, such as some biocontrol PGPRs, primes the plant to react faster and more strongly to a subsequent pathogen attack (Olanrewaju et al., 2017). Induction of systemic resistance provides strong protection coordinated by phytohormone signaling pathways (Pieterse et al., 2012, 2014; Walters et al., 2013); (vi) quorum quenching, which is the disruption of signaling among pathogens. This may occur via the production of signal-degrading enzymes such as lactonase, and the subsequent loss of disruption of signaling may minimize pathogen virulence (Olanrewaju et al., 2017); and (vii) synthesis of siderophores (Olanrewaju et al., 2017), which can prevent or reduce pathogen proliferation by reducing the iron available to pathogens (Shen et al., 2013). The siderophores from PGPRs have been found, at least in some cases, to have a higher affinity for $\mathrm{Fe}^{3+}$ than the siderophores from fungal pathogens (Kloepper et al., 1980), thus giving the PGPRs a competitive advantage for iron.

Halophilic PGPRs may also provide biological control of phytopathogens. Many can produce antibiotics and antifungal metabolites, as shown in the halophilic bacteria $B$. subtilis, 
B. cereus, B. pumilus, B. licheniformis, Halomonas elongate, and Halobacillus halophilus, which antagonize phytopathogenic fungi such as Fusarium sambucinum, F. roseum var. sambucinum, F. oxysporum, F. moniliforme, F. graminearum, Penicillium citrinum, Aspergillus flavus, and Botrytis cinerea; these organisms have been shown to produce antibiotics, proteases, chitinases, and $\beta$-1,3-glucanases (Niehaus et al., 1999; Sadfi et al., 2001, 2002; Sadfi-Zouaoui et al., 2008; Essghaier et al., 2009; Siddikee et al., 2010; Berrada et al., 2012; Ruppel et al., 2013; Goswami et al., 2014; Singh and Jha, 2016). For example, the strains $B$. halotolerans Ps9 and B. pumilus Ps19, which were isolated from the halophyte $P$. strombulifera, exhibited protease activity and inhibited the growth of the phytopathogenic fungus Alternaria sp. by more than 50\%, at least on plates (Sgroy et al., 2009). Similarly, a halotolerant PGPR Pseudomonas sp. strain isolated from the halophyte Suaeda salsa suppressed the growth of the phytopathogenic fungi Fusarium oxysporum f. sp. cucumerinum and F. oxysporum f. sp. conglutinans (Teng et al., 2010). The biological control potential of halophilic bacteria may be correlated with their production of membrane-bound or extracellular hydrolytic enzymes (Sadfi-Zouaoui et al., 2008). Although antagonistic halotolerant PGPRs may provide an ecologically friendly alternative to synthetic fungicides, research is needed to evaluate that antagonistic potential of halotolerant PGPRs against phytopathogens, and the severity of the disease pressure by these pathogens, in saline environments (SadfiZouaoui et al., 2008).

\section{CONCLUSIONS AND FUTURE PROSPECTS}

This review has highlighted the potential for halophytes to be used as an isolation source for halotolerant PGPRs, including PGPRs that exhibit PGP traits such as IAA production, phosphate solubilization, siderophore production, $\mathrm{N}_{2}$ fixation, ACC deaminase activity, and control of phytopathogens. Halotolerant PGPRs isolated from the endosphere or rhizosphere of halophytes can be used to enhance the growth, and possibly the yield, of halophytic and non-halophytic crops (Sáenz-Mata et al., 2016). Crop inoculation with halotolerant PGPRs is therefore a viable strategy for sustainable crop production in salinity-based agriculture, which includes crop production in arid and semiarid environments (Khan et al., 2016). Several avenues of research would move us closer to adopting this strategy for salinity-based agriculture:

(i) Although some beneficial effects of halotolerant PGPRs on salinity-affected plants are known, many of the underlying physiological and molecular mechanisms contributing to enhanced plant growth and halotolerance are not. Knowledge of these mechanisms, and the portfolio of traits optimal for inoculum performance, would contribute to designing agronomic applications of these bacteria for saline-based agriculture (Dodd and Pérez-Alfocea, 2012).

(ii) Knowledge of how the endogenous bacterial and fungal microbiomes of halophytes contribute to halophyte resistance to extreme salinity would provide insights into optimal applications of introduced halotolerant PGPRs.

(iii) Increasing global food production requires improved crop production not only in saline soils, but also in areas where the irrigation water is contaminated with salt (Ruppel et al., 2013). This is an increasing problem in coastal zones and thus will be increasingly important in many parts of the world. Halophytes should be explored as a reservoir for halotolerant PGPRs for uses under these conditions as well as in saline soils.

(iv) Since the diversity of halotolerant PGPRs in salt-affected soils and in the microbiome of halophytic plants depends on soil parameters and plant species (Qin et al., 2016; Szymańska, et al., 2016), further studies on the diversity of the microbial communities in the rhizosphere and endosphere of various halophytic plant species are needed to clarify and describe these ecological associations in saline soil-based agriculture.

(v) Knowledge of the signaling mechanisms and factors influencing the interactions between halotolerant PGPRs and halophytes and glycophytes in the field will provide a better understanding of the ecology of these bacteria and how they have promoted halophyte adaptation to high salinity environments (Egamberdiyeva and Islam, 2008; Khan et al., 2016).

(vi) Knowledge of the biochemical and physiological characteristics of PGPRs associated with halophytes could facilitate strategies for plant protection and remediation of saline soils (Ruppel et al., 2013; Egamberdieva and Lugtenberg, 2014; Khan et al., 2016).

(vii) Agricultural inoculants, including those for bio-stimulation, often vary in efficacy due, in part, to their strong dependence on environmental context for activity. Although the isolation of halotolerant PGPRs from halophytes in saline soils should increase the probability that the strains are active in saline soils (Khan et al., 2009), knowledge of the key environmental traits that influence their activity could help reduce variation in efficacy. Moreover, isolating PGPRs from roots under conditions of high alkalinity, acidity or salinity, drought, high and low temperatures, and flooded conditions could provide strains or traits that are efficacious in plant protection or growth promotion under diverse agricultural conditions (Khan et al., 2016).

(viii) Knowledge of the molecular mechanisms by which salttolerant PGPRs increase plant resistance to salinity may suggest genetic approaches to engineer bacteria with enhanced abilities to stimulate plant growth and salinity tolerance, as well as plants that are improved in their ability to interact with halotolerant PGPRs (Khan et al., 2016).

(ix) Knowledge of the endophytic and rhizospheric fungi associated with halophytes and their impacts on halophyte growth and survival may contribute to additional strategies for protecting halophyte and non-halophyte plants in saline soils (Sharma et al., 2016).

(x) To increase our fundamental knowledge of microbial interactions with halophytes, investigations are needed that address the specificity of halophyte-microbe 
interactions, the effect of root exudates on these interactions, and the effect of root exudates on gene expression related to plant growth promotion and biological control.

(xi) Lastly, the development of halotolerant PGPRs that can sustainably improve plant growth under diverse high salinity crop production conditions requires that the performance of these strains be examined over long periods (at least 2 years) on a scale that is relevant to crop production and under field conditions that provide a diversity of soil conditions and environmental stresses. Sustainable improvements in crop productivity may benefit from strategies that combine PGPRs with stresstolerant beneficial fungi, and that involve co-inoculating multiple PGPRs that alleviate distinct stresses. The latter is particularly appealing given the co-occurrence of

\section{REFERENCES}

Abbas, G., Saqib, M., and Akhtar, J. (2015). Interactive effects of salinity and iron deficiency on different rice genotypes. J. Plant Nutr. Soil Sci. 178, 306-311. doi: 10.1002/jpln.201400358

Abou-Elela, S. I., Kamel, M. M., and Fawzy, M. E. (2010). Biological treatment of saline wastewater using a salt-tolerant microorganism. Desalination 250, 1-5. doi: 10.1016/j.desal.2009.03.022

Acquaah, G. (2007). Principles of Plant Genetics and Breeding. Oxford: Blackwell.

Ahmad, P., Azooz, M. M., and Prasad, M. N. V. (eds.). (2013). Salt Stress in Plants. New York, NY: Springer, 1-495. doi: 10.1007/978-1-4614-6108-1

Ahmad, P., Rasool, S., Gul, A., Sheikh, S. A., Akram, N. A., Ashraf, M., et al. (2016). Jasmonates: multifunctional roles in stress tolerance. Front. Plant Sci. 7:813. doi: 10.3389/fpls.2016.00813

Akhavan-Kharazian, M., Campbell, W. F., Jurinak, J. J., and Dudley, L. M. (1991). Effects of $\mathrm{CaSO} 4, \mathrm{CaCl} 2$, and $\mathrm{NaCl}$ on leaf nitrogen, nodule weight, and acetylene reduction activity in Phaseolus vulgaris L. Arid Land Res. Manage. 5, 97-103.

Akinshina, N., Azizov, A., Karasyova, T., and Klose, E. (2016). On the issue of halophytes as energy plants in saline environment. Biomass Bioener. 91, 306-311. doi: 10.1016/j.biombioe.2016.05.034

Albacete, A., Ghanem, M. E., Martínez-Andújar, C., Acosta, M., SánchezBravo, J., Martínez, V., et al. (2008). Hormonal changes in relation to biomass partitioning and shoot growth impairment in salinized tomato (Solanum lycopersicum L.) plants. J. Exp. Bot. 59, 4119-4131. doi: 10.1093/jxb/ ern251

Ali, S., Charles, T. C., and Glick, B. R. (2014). Amelioration of high salinity stress damage by plant growth-promoting bacterial endophytes that contain ACC deaminase. Plant Physiol. Biochem. 80, 160-167. doi: 10.1016/j.plaphy.2014.04.003

Al-Mailem, D. M., Sorkhoh, N. A., Marafie, M., Al-Awadhi, H., Eliyas, M., and Radwan, S. S. (2010). Oil phytoremediation potential of hypersaline coasts of the Arabian Gulf using rhizosphere technology. Bioresour. Technol. 101, 5786-5792. doi: 10.1016/j.biortech.2010.02.082

Anburaj, R., Nabeel, M. A., Sivakumar, T., and Kathiresan, K. (2012). The role of rhizobacteria in salinity effects on biochemical constituents of the halophyte Sesuvium portulacastrum. Russ. J. Plant Physiol. 59, 115-119. doi: 10.1134/S1021443712010025

Antón, J., Oren, A., Benlloch, S., Rodríguez-Valera, F., Amann, R., and RossellóMora, R. (2002). Salinibacter ruber gen. nov., sp. nov., a novel, extremely halophilic member of the Bacteria from saltern crystallizer ponds. Int. J. Syst. Evol. Microbiol. 52, 485-491. doi: 10.1099/00207713-52-2-485

Argandona, M., Fernandez-Carazo, R., Llamas, I., Martinez-Checa, F., Caba, J. M., Quesada, E., et al. (2005). The moderately halophilic bacterium Halomonas maura is a free-living diazotroph. FEMS Microbiol. Lett. 244, 69-74. doi: 10.1016/j.femsle.2005.01.019 many stresses, such as drought, salinity, and heavy metal contamination, in field soils. Importantly, halotolerant PGPRs that are used effectively in agriculture may also contribute to applications for phytoremediation, phytodesalinization, bio-fertilization, and biological control.

\section{AUTHOR CONTRIBUTIONS}

HE gathered literature and prepared the manuscript. GB revised and approved the final version to be published.

\section{ACKNOWLEDGMENTS}

We wish to thank University of Tehran and Iowa State University for providing the necessary facilities for this study.

Arkhipova, T. N., Prinsen, E., Veselov, S. U., Martinenko, E. V., Melentiev, A. I., and Kudoyarova, G. R. (2007). Cytokinin producing bacteria enhance plant growth in drying soil. Plant Soil 292, 305-315. doi: 10.1007/s11104-0079233-5

Arora, N. K., Singhal, V., and Maheshwari, D. K. (2006). Salinity-induced accumulation of poly- $\beta$-hydroxybutyrate in rhizobia indicating its role in cell protection. World J. Microbiol. Biotechnol. 22, 603-606. doi: 10.1007/s11274-005-9077-1

Arora, N. K., Tewari, S., Singh, S., Lal, N., and Maheshwari, D. K. (2012). "PGPR for protection of plant health under saline conditions," in Bacteria in Agrobiology: Stress Management, ed D. K. Maheshwari (Berlin; Heidelberg: Springer-Verlag), 239-258.

Arshad, M., and Frankenberger, W. T. Jr. (1991). "Microbial production of plant hormones," in The Rhizosphere and Plant Growth, eds D. L. Keister and P. B. Cregan (Dordrecht: Springer), 327-334.

Ashraf, M., Hasnain, S., Berge, O., and Mahmood, T. (2004). Inoculating wheat seedlings with exopolysaccharide-producing bacteria restricts sodium uptake and stimulates plant growth under salt stress. Biol. Fertil. Soils 40, 157-162. doi: 10.1007/s00374-004-0766-y

Askari, H., Edqvist, J., Hajheidari, M., Kafi, M., and Salekdeh, G. H. (2006). Effects of salinity levels on proteome of Suaeda aegyptiaca leaves. Proteomics 6, 2542-2554. doi: 10.1002/pmic.200500328

Banaei-Asl, F., Bandehagh, A., Uliaei, E. D., Farajzadeh, D., Sakata, K., Mustafa, G., et al. (2015). Proteomic analysis of canola root inoculated with bacteria under salt stress. J. Proteomics 124, 88-111. doi: 10.1016/j.jprot.2015.04.009

Banerjee, S., Palit, R., Sengupta, C., and Standing, D. (2010). Stress induced phosphate solubilization By 'arthrobacter' sp. and 'Bacillus' sp. isolated from tomato rhizosphere. Aust. J. Crop Sci. 4, 378.

Barahona, E., Navazo, A., Martínez-Granero, F., Zea-Bonilla, T., Pérez-Jiménez, R. M., Martín, M., et al. (2011). Pseudomonas fluorescens F113 mutant with enhanced competitive colonization ability and improved biocontrol activity against fungal root pathogens. Appl. Environ. Microbiol. 77, 5412-5419. doi: 10.1128/AEM.00320-11

Barnawal, D., Bharti, N., Maji, D., Chanotiya, C. S., and Kalra, A. (2012). 1-Aminocyclopropane-1-carboxylic acid (ACC) deaminase-containing rhizobacteria protect Ocimum sanctum plants during waterlogging stress via reduced ethylene generation. Plant Physiol. Biochem. 58, 227-235. doi: 10.1016/j.plaphy.2012.07.008

Bashan, Y., Moreno, M., and Troyo, E. (2000). Growth promotion of the seawaterirrigated oilseed halophyte Salicornia bigelovii inoculated with mangrove rhizosphere bacteria and halotolerant Azospirillum spp. Biol. Fertil. Soils 32, 265-272. doi: 10.1007/s003740000246

Belimov, A. A., Dodd, I. C., Safronova, V. I., Dumova, V. A., Shaposhnikov, A. I., Ladatko, A. G., et al. (2014). Abscisic acid metabolizing rhizobacteria decrease ABA concentrations in planta and alter plant growth. Plant Physiol. Biochem. 74, 84-91. doi: 10.1016/j.plaphy.2013.10.032 
Berendsen, R. L., Pieterse, C. M. J., and Bakker, P. A. (2012). The rhizosphere microbiome and plant health. Trends Plant Sci. 17, 478-486. doi: 10.1016/j.tplants.2012.04.001

Berrada, I., Benkhemmar, O., Swings, J., Bendaou, N., and Amar, M. (2012). Selection of halophilic bacteria for biological control of tomato gray mould caused by Botrytis cinerea. Phytopathol. Mediterr. 51, 625-630. doi: 10.14601/ Phytopathol_Mediterr-10627

Besri, M. (1993). "Effects of salinity on plant diseases development," in Towards the Rational Use of High Salinity Tolerant Plants, eds H. Lieth and A. A. Al Masoom (Springer Netherlands), 67-74.

Bharti, N., Pandey, S. S., Barnawal, D., Patel, V. K., and Kalra, A. (2016). Plant growth promoting rhizobacteria Dietzia natronolimnaea modulates the expression of stress responsive genes providing protection of wheat from salinity stress. Sci. Rep. 6:34768. doi: 10.1038/srep34768

Bharti, N., Yadav, D., Barnawal, D., Maji, D., and Kalra, A. (2013). Exiguobacterium oxidotolerans, a halotolerant plant growth promoting rhizobacteria, improves yield and content of secondary metabolites in Bacopa monnieri (L.) Pennell under primary and secondary salt stress. World J. Microbiol. Biotechnol. 29, 379-387. doi: 10.1007/s11274-012-1192-1

Bhattacharyya, P. N., and Jha, D. K. (2012). Plant growth-promoting rhizobacteria (PGPR): emergence in agriculture. World J. Microbiol. Biotechnol. 28, 1327-1350. doi: 10.1007/s11274-011-0979-9

Bian, G., Zhang, Y., Qin, S., Xing, K., Xie, H., and Jiang, J. (2011). Isolation and biodiversity of heavy metal tolerant endophytic bacteria from halotolerant plant species located in coastal shoal of Nantong. Wei Sheng Wu Xue Bao 51, 1538-1547.

Bianco, C., and Defez, R. (2009). Medicago truncatula improves salt tolerance when nodulated by an indole-3-acetic acid-overproducing Sinorhizobium meliloti strain. J. Exp. Bot. 60, 3097-3107. doi: 10.1093/jxb/erp140

Bianco, C., Imperlini, E., Calogero, R., Senatore, B., Amoresano, A., Carpentieri, A., et al. (2006). Indole-3-acetic acid improves Escherichia coli's defences to stress. Arch. Microbiol. 185, 373-382. doi: 10.1007/s00203-00 6-0103-y

Bibi, F., Chung, E. J., Yoon, H. S., Song, G. C., Jeon, C. O., and Chung, Y. R. (2011). Haloferula luteola sp. nov., an endophytic bacterium isolated from the root of a halophyte, Rosa rugosa, and emended description of the genus Haloferula. Int. J. Syst. Evol. Microbiol. 61, 1837-1841. doi: 10.1099/ijs.0.022772-0

Bordiec, S., Paquis, S., Lacroix, H., Dhondt, S., Ait Barka, E., Kauffmann, S., et al. (2010). Comparative analysis of defence responses induced by the endophytic plant growth-promoting rhizobacterium Burkholderia phytofirmans strain PsJN and the non-host bacterium Pseudomonas syringae pv. pisi in grapevine cell suspensions. J. Exp. Bot. 62, 595-603. doi: 10.1093/jxb/erq291

Bottini, R., Cassán, F., and Piccoli, P. (2004). Gibberellin production by bacteria and its involvement in plant growth promotion and yield increase. Appl. Microbiol. Biotechnol. 65, 497-503. doi: 10.1007/s00253-004-1696-1

Boukhatem, Z. F., Domergue, O., Bekki, A., Merabet, C., Sekkour, S., Bouazza, F., et al. (2012). Symbiotic characterization and diversity of rhizobia associated with native and introduced acacias in arid and semi-arid regions in Algeria. FEMS Microbiol. Ecol. 80, 534-547. doi: 10.1111/j.1574-6941.2012.01315.x

Bruning, B., and Rozema, J. (2013). Symbiotic nitrogen fixation in legumes: perspectives for saline agriculture. Environ. Exp. Bot. 92, 134-143. doi: 10.1016/j.envexpbot.2012.09.001

Bruto, M., Prigent-Combaret, C., Muller, D., and Moënne-Loccoz, Y. (2014). Analysis of genes contributing to plant-beneficial functions in plant growth-promoting rhizobacteria and related Proteobacteria. Sci. Rep. 4:6261. doi: 10.1038/srep06261

Camilios-Neto, D., Bonato, P., Wassem, R., Tadra-Sfeir, M. Z., BrusamarelloSantos, L. C. C., Valdameri, G., et al. (2014). Dual RNA-seq transcriptional analysis of wheat roots colonized by Azospirillum brasilense reveals upregulation of nutrient acquisition and cell cycle genes. BMC Genomics 15:378. doi: 10.1186/1471-2164-15-378

Cheeseman, J. M. (2015). The evolution of halophytes, glycophytes and crops, and its implications for food security under saline conditions. New Phytol. 206, 557-570. doi: 10.1111/nph.13217

Chen, Y., Fan, J.-B., Du, L., Xu, H., Zhang, Q.-H., and He, Y.-Q. (2014). The application of phosphate solubilizing endophyte Pantoea dispersa triggers the microbial community in red acidic soil. Appl. Soil Ecol. 84, 235-244. doi: 10.1016/j.apsoil.2014.05.014
Cheng, Z., Park, E., and Glick, B. R. (2007). 1-Aminocyclopropane-1-carboxylate deaminase from Pseudomonas putida UW4 facilitates the growth of canola in the presence of salt. Can. J. Microbiol. 53, 912-918. doi: 10.1139/W07-050

Chernin, L., Ismailov, Z., Haran, S., and Chet, I. (1995). Chitinolytic Enterobacter agglomerans antagonistic to fungal plant pathogens. Appl. Environ. Microbiol. $61,1720-1726$

Cohen, A. C., Bottini, R., Pontin, M., Berli, F. J., Moreno, D., Boccanlandro, H., et al. (2015). Azospirillum brasilense ameliorates the response of Arabidopsis thaliana to drought mainly via enhancement of ABA levels. Physiol. Plant. 153, 79-90. doi: 10.1111/ppl.12221

Compant, S., Clément, C., and Sessitsch, A. (2010). Plant growth-promoting bacteria in the rhizo- and endosphere of plants: their role, colonization, mechanisms involved and prospects for utilization. Soil Biol. Biochem. 42, 669-678. doi: 10.1016/j.soilbio.2009.11.024

Couillerot, O., Prigent-Combaret, C., Caballero-Mellado, J., and MoënneLoccoz, Y. (2009). Pseudomonas fluorescens and closely-related fluorescent pseudomonads as biocontrol agents of soil-borne phytopathogens. Lett. Appl. Microbiol. 48, 505-512. doi: 10.1111/j.1472-765X.2009. 02566. $\mathrm{x}$

Creus, C. M., Sueldo, R. J., and Barassi, C. A. (2004). Water relations and yield in Azospirillum-inoculated wheat exposed to drought in the field. Can. J. Bot. 82, 273-281. doi: 10.1139/b03-119

Datta, K. S., Varma, S. K., Angrish, R., Kumar, B., and Kumari, P. (1997). Alleviation of salt stress by plant growth regulators in Triticum aestivum L. Biol. Plant. 40, 269-275. doi: 10.1023/A:1001076805595

de Garcia Salamone, I. E., Hynes, R. K., and Nelson, L. M. (2005). "Role of cytokinins in plant growth promotion by rhizosphere bacteria," in PGPR: Biocontrol and Biofertilization, ed Z. A. Siddiqui (Springer Netherlands), 173-195.

del Amor, F. M., and Cuadra-Crespo, P. (2012). Plant growth-promoting bacteria as a tool to improve salinity tolerance in sweet pepper. Funct. Plant Biol. 39, 82-90. doi: 10.1071/FP11173

de la Peña, T. C., and Pueyo, J. J. (2012). Legumes in the reclamation of marginal soils, from cultivar and inoculant selection to transgenic approaches. Agron. Sustain. Dev. 32, 65-91. doi: 10.1007/s13593-011-0024-2

Del Río, L. A. (2015). ROS and RNS in plant physiology: an overview. J. Exp. Bot. 66, 2827-2837. doi: 10.1093/jxb/erv099

Djekoun, A., and Planchon, C. (1991). Water status effect on dinitrogen fixation and photosynthesis in soybean. Agron. J. 83, 316-322. doi: 10.2134/agronj1991.00021962008300020011x

Dodd, I. C. (2003). Hormonal interactions and stomatal responses. J. Plant Growth Regul. 22, 32-46. doi: 10.1007/s00344-003-0023-x

Dodd, I. C., and Pérez-Alfocea, F. (2012). Microbial amelioration of crop salinity stress. J. Exp. Bot. 63, 3415-3428. doi: 10.1093/jxb/ers033

Dodd, I. C., Zinovkina, N. Y., Safronova, V. I., and Belimov, A. A. (2010). Rhizobacterial mediation of plant hormone status. Ann. Appl. Biol. 157, 361-379. doi: 10.1111/j.1744-7348.2010.00439.x

Dunlap, J. R., and Binzel, M. L. (1996). NaCI reduces indole-3-acetic acid levels in the roots of tomato plants independent of stress-induced abscisic acid. Plant Physiol. 112, 379-384. doi: 10.1104/pp.112.1.379

Dutta, S., and Khurana, S. M. P. (2015). "Plant growth-promoting rhizobacteria for alleviating abiotic stresses in medicinal plants," in Plant-Growth-Promoting Rhizobacteria (PGPR) and Medicinal Plants, eds D. Egamberdieva, S. Shrivastava, and A. Varma (Springer), 167-200.

Egamberdieva, D. (2009). Alleviation of salt stress by plant growth regulators and IAA producing bacteria in wheat. Acta Physiol. Plant. 31, 861-864. doi: 10.1007/s11738-009-0297-0

Egamberdieva, D., and Kucharova, Z. (2009). Selection for root colonising bacteria stimulating wheat growth in saline soils. Biol. Fertil. Soils 45, 563-571. doi: 10.1007/s00374-009-0366-y

Egamberdieva, D., and Lugtenberg, B. (2014). "Use of plant growth-promoting rhizobacteria to alleviate salinity stress in plants," in Use of Microbes for the Alleviation of Soil Stresses, Vol. 1, ed M. Miransari (New York, NY: Springer), 73-96.

Egamberdiyeva, D., and Islam, K. R. (2008). "Salt-tolerant rhizobacteria: plant growth promoting traits and physiological characterization within ecologically stressed environments," in Plant-Bacteria Interactions: Strategies and Techniques to Promote Plant Growth, eds I. Ahmad, J. Pichtel, and 
S. Hayat (Weinheim: Wiley-VCH Verlag GmbH \& Co., KGaA), 257-281. doi: 10.1002/9783527621989.ch14

El-Tarabily, K. A., and Youssef, T. (2010). Enhancement of morphological, anatomical and physiological characteristics of seedlings of the mangrove Avicennia marina inoculated with a native phosphate-solubilizing isolate of Oceanobacillus picturae under greenhouse conditions. Plant Soil 332, 147-162. doi: 10.1007/s11104-010-0280-y

Essghaier, B., Fardeau, M.-L., Cayol, J.-L., Hajlaoui, M. R., Boudabous, A., Jijakli, H., et al. (2009). Biological control of grey mould in strawberry fruits by halophilic bacteria. J. Appl. Microbiol. 106, 833-846. doi: 10.1111/j.1365-2672.2008.04053.x

Etesami, H. (2018). Can interaction between silicon and plant growth promoting rhizobacteria benefit in alleviating abiotic and biotic stresses in crop plants? Agric. Ecosyst. Environ. 253, 98-112. doi: 10.1016/j.agee.2017.11.007

Etesami, H., and Alikhani, H. A. (2018). Bacillus species as the most promising bacterial biocontrol agents in rhizosphere and endorhiza of plants grown in rotation with each other. Eur. J. Plant Pathol. 150, 497-506. doi: 10.1007/ s10658-017-1276-8

Etesami, H., and Beattie, G. A. (2017). "Plant-microbe interactions in adaptation of agricultural crops to abiotic stress conditions," in Probiotics and Plant Health, eds V. Kumar, M. Kumar, S. Sharma, and R. Prasad (Singapore: Springer), 163-200.

Etesami, H., Hosseini, H. M., and Alikhani, H. A. (2014). Bacterial biosynthesis of 1-aminocyclopropane-1-caboxylate (ACC) deaminase, a useful trait to elongation and endophytic colonization of the roots of rice under constant flooded conditions. Physiol. Mol. Biol. Plants 20, 425-434. doi: 10.1007/s12298-014-0251-5

Flowers, T. J., and Colmer, T. D. (2008). Salinity tolerance in halophytes. New Phytol. 179, 945-963. doi: 10.1111/j.1469-8137.2008.02531.x

Flowers, T. J., and Colmer, T. D. (2015). Plant salt tolerance: adaptations in halophytes. Ann. Bot. 115, 327-331. doi: 10.1093/aob/mcu267

Forchetti, G., Masciarelli, O., Alemano, S., Alvarez, D., and Abdala, G. (2007). Endophytic bacteria in sunflower (Helianthus annuus L.): isolation, characterization, and production of jasmonates and abscisic acid in culture medium. Appl. Microbiol. Biotechnol. 76, 1145-1152. doi: 10.1007/s00253-007-1077-7

Gago, C., Sousa, A. R., Juliao, M., Miguel, G., Antunes, D. C., and Panagopoulos, T. (2011). Sustainable use of energy in the storage of halophytes used for food. Int. J. Ener. Environ. 5, 592-599.

Gamalero, E., and Glick, B. R. (2015). Bacterial modulation of plant ethylene levels. Plant Physiol. 169, 13-22. doi: 10.1104/pp.15.00284

Giongo, A., Ambrosini, A., Vargas, L. K., Freire, J. R. J., Bodanese-Zanettini, M. H., and Passaglia, L. M. P. (2008). Evaluation of genetic diversity of bradyrhizobia strains nodulating soybean [Glycine max (L.) Merrill] isolated from South Brazilian fields. Appl. Soil Ecol. 38, 261-269. doi: 10.1016/j.apsoil.2007.10.016

Giri, B., Kapoor, R., Agarwal, L., and Mukerji, K. G. (2004). Preinoculation with arbuscular mycorrhizae helps Acacia auriculiformis grow in degraded Indian wasteland soil. Commun. Soil Sci. Plant Anal. 35, 193-204. doi: $10.1081 /$ CSS-120027643

Giri, B., Kapoor, R., and Mukerji, K. G. (2007). Improved tolerance of Acacia nilotica to salt stress by arbuscular mycorrhiza, Glomus fasciculatum may be partly related to elevated K/Na ratios in root and shoot tissues. Microb. Ecol. 54, 753-760. doi: 10.1007/s00248-007-9239-9

Glenn, E. P., O'Leary, J. W., Watson, M. C., Thompson, T. L., and Kuehl, R. O. (1991). Salicornia bigelovii Torr.: an oilseed halophyte for seawater irrigation. Science 251, 1065-1068.

Glick, B. R. (2004). Bacterial ACC deaminase and the alleviation of plant stress. Adv. Appl. Microbiol. 56, 291-312. doi: 10.1016/S0065-2164(04)56009-4

Glick, B. R. (2012). Plant growth-promoting bacteria: mechanisms and applications. Scientifica 2012:963401. doi: 10.6064/2012/963401

Glick, B. R. (2014). Bacteria with ACC deaminase can promote plant growth and help to feed the world. Microbiol. Res. 169, 30-39. doi: 10.1016/j.micres.2013.09.009

Glick, B. R., and Bashan, Y. (1997). Genetic manipulation of plant growthpromoting bacteria to enhance biocontrol of phytopathogens. Biotechnol. Adv. 15, 353-378. doi: 10.1016/S0734-9750(97)00004-9

Glick, B. R., Cheng, Z., Czarny, J., and Duan, J. (2007). Promotion of plant growth by ACC deaminase-producing soil bacteria.
Eur. J. Plant Pathol. 119, 329-339. doi: 10.1007/s10658-0079162-4

Godfray, H. C. J., Beddington, J. R., Crute, I. R., Haddad, L., Lawrence, D., Muir, J. F., et al. (2010). Food security: the challenge of feeding 9 billion people. Science 327, 812-818. doi: 10.1126/science. 1185383

Goldstein, A. H. (1986). Bacterial solubilization of mineral phosphates: historical perspective and future prospects. Am. J. Altern. Agric. 1, 51-57. doi: $10.1017 /$ S0889189300000886

Gond, S. K., Torres, M. S., Bergen, M. S., Helsel, Z., and White, J. F. (2015). Induction of salt tolerance and up-regulation of aquaporin genes in tropical corn by rhizobacterium Pantoea agglomerans. Lett. Appl. Microbiol. 60, 392-399. doi: 10.1111/lam.12385

Gontia, I., Kavita, K., Schmid, M., Hartmann, A., and Jha, B. (2011). Brachybacterium saurashtrense sp. nov., a halotolerant root-associated bacterium with plant growth-promoting potential. Int. J. Syst. Evol. Microbiol. 61, 2799-2804. doi: 10.1099/ijs.0.023176-0

Goswami, D., Dhandhukia, P., Patel, P., and Thakker, J. N. (2014). Screening of PGPR from saline desert of Kutch: growth promotion in Arachis hypogea by Bacillus licheniformis A2. Microbiol. Res. 169, 66-75. doi: 10.1016/j.micres.2013.07.004

Großkinsky, D. K., Naseem, M., Abdelmohsen, U. R., Plickert, N., Engelke, T., Griebel, T., et al. (2011). Cytokinins mediate resistance against Pseudomonas syringae in tobacco through increased antimicrobial phytoalexin synthesis independent of salicylic acid signaling. Plant Physiol. 157, 815-830. doi: 10.1104/pp.111.182931

Guo, H., Wang, Y., Liu, H., Hu, P., Jia, Y., Zhang, C., et al. (2015). Exogenous GA3 application enhances xylem development and induces the expression of secondary wall biosynthesis related genes in Betula platyphylla. Int. J. Mol. Sci. 16, 22960-22975. doi: 10.3390/ijms160922960

Gupta, B., and Huang, B. (2014). Mechanism of salinity tolerance in plants: physiological, biochemical, and molecular characterization. Int. J. Genomics 2014:701596. doi: 10.1155/2014/701596

Halfeld-Vieira, B. d. A., Vieira Júnior, J. R., Romeiro, R.d. S., Silva, H. S. A., and Baracat-Pereira, M. C. (2006). Induction of systemic resistance in tomato by the autochthonous phylloplane resident Bacillus cereus. Pesqui. Agropecu. Bras. 41, 1247-1252. doi: 10.1590/S0100-204X2006000800006

Hardoim, P. R., van Overbeek, L. S., and Elsas, J. D. V. (2008). Properties of bacterial endophytes and their proposed role in plant growth. Trends Microbiol. 16, 463-471. doi: 10.1016/j.tim.2008.07.008

Hasanuzzaman, M., Nahar, K., Alam, M. M., Bhowmik, P. C., Hossain, M. A., Rahman, M. M., et al. (2014). Potential use of halophytes to remediate saline soils. Biomed. Res. Int. 2014:589341. doi: 10.1155/2014/ 589341

Hasegawa, P. M., Bressan, R. A., Zhu, J.-K., and Bohnert, H. J. (2000). Plant cellular and molecular responses to high salinity. Annu. Rev. Plant Biol. 51, 463-499. doi: 10.1146/annurev.arplant.51.1.463

Himabindu, Y., Chakradhar, T., Reddy, M. C., Kanygin, A., Redding, K. E., and Chandrasekhar, T. (2016). Salt-tolerant genes from halophytes are potential key players of salt tolerance in glycophytes. Environ. Exp. Bot. 124, 39-63. doi: 10.1016/j.envexpbot.2015.11.010

Husson, E., Hadad, C., Huet, G., Laclef, S., Lesur, D., Lambertyn, V., et al. (2017). The effect of room temperature ionic liquids on the selective biocatalytic hydrolysis of chitin via sequential or simultaneous strategies. Green Chem. 19, 4122-4131. doi: 10.1039/C7GC01471F

Ilangumaran, G., and Smith, D. L. (2017). Plant growth promoting rhizobacteria in amelioration of salinity stress: a systems biology perspective. Front. Plant Sci. 8:1768. doi: 10.3389/fpls.2017.01768

Islam, F., Yasmeen, T., Arif, M. S., Ali, S., Ali, B., Hameed, S., et al. (2016). Plant growth promoting bacteria confer salt tolerance in Vigna radiata by upregulating antioxidant defense and biological soil fertility. Plant Growth Regul. 80, 23-36. doi: 10.1007/s10725-015-0142-y

Jacob, J. H. (2012). Classification of halophilic heterotrophic bacteria thriving in the jordanian dead sea littoral zone. J. Biol. Sci. 12, 246-252. doi: $10.3923 /$ jbs.2012.246.252

Jafari, B., Hanifezadeh, M., and Parvin, M. S. J. (2012). Molecular study of bacteria associated with Salicornia symbiotic bacteria as a candidate for Hormozgan salty zone culturing by Persian Gulf water irrigation. Afr. J. Microbiol. Res. 6, 4687-4695. doi: 10.5897/AJMR11.1132 
Jasim, B., Anish, M. C., Shimil, V., Jyothis, M., and Radhakrishnan, E. K. (2015). Studies on plant growth promoting properties of fruit-associated bacteria from Elettaria cardamomum and molecular analysis of ACC deaminase gene. Appl. Biochem. Biotechnol. 177, 175-189. doi: 10.1007/s12010-015$1736-6$

Jesus, J. M., Danko, A. S., Fiúza, A., and Borges, M.-T. (2015). Phytoremediation of salt-affected soils: a review of processes, applicability, and the impact of climate change. Environ. Sci. Pollut. Res. 22, 6511-6525. doi: 10.1007/s11356-015-4205-4

Jha, B., Gontia, I., and Hartmann, A. (2012). The roots of the halophyte Salicornia brachiata are a source of new halotolerant diazotrophic bacteria with plant growth-promoting potential. Plant Soil 356, 265-277. doi: 10.1007/s11104-011-0877-9

Jha, B., Singh, V. K., Weiss, A., Hartmann, A., and Schmid, M. (2015). Zhihengliuella somnathii sp. nov., a halotolerant actinobacterium from the rhizosphere of a halophyte Salicornia brachiata. Int. J. Syst. Evol. Microbiol. 65, 3137-3142. doi: 10.1099/ijsem.0.000391

Jha, Y., and Subramanian, R. B. (2014). PGPR regulate caspase-like activity, programmed cell death, and antioxidant enzyme activity in paddy under salinity. Physiol. Mol. Biol. Plants 20, 201-207. doi: 10.1007/s12298-0140224-8

Ji, S. H., Gururani, M. A., and Chun, S.-C. (2014). Isolation and characterization of plant growth promoting endophytic diazotrophic bacteria from Korean rice cultivars. Microbiol. Res. 169, 83-98. doi: 10.1016/j.micres.2013.06.003

Jiang, F., Chen, L., Belimov, A. A., Shaposhnikov, A. I., Gong, F., Meng, X., et al. (2012). Multiple impacts of the plant growth-promoting rhizobacterium Variovorax paradoxus $5 \mathrm{C}-2$ on nutrient and $\mathrm{ABA}$ relations of Pisum sativum. J. Exp. Bot. 63, 6421-6430. doi: 10.1093/jxb/ers301

Joo, G.-J., Kim, Y.-M., Kim, J.-T., Rhee, I.-K., Kim, J.-H., and Lee, I.-J. (2005). Gibberellins-producing rhizobacteria increase endogenous gibberellins content and promote growth of red peppers. J. Microbiol. 43, 510-515.

Joshi, R., Mangu, V. R., Bedre, R., Sanchez, L., Pilcher, W., Zandkarimi, H., et al. (2015). "Salt adaptation mechanisms of halophytes: improvement of salt tolerance in crop plants," in Elucidation of Abiotic Stress Signaling in Plants, ed G. K. Pandey (New York, NY: Springer), 243-279.

Kafi, M., and Khan, M. A. (2008). Crop and Forage Production using Saline Waters. Daya Books.

Kang, S.-M., Khan, A. L., Hamayun, M., Hussain, J., Joo, G.-J., You, Y.H., et al. (2012). Gibberellin-producing Promicromonospora sp. SE188 improves Solanum lycopersicum plant growth and influences endogenous plant hormones. J. Microbiol. 50, 902. doi: 10.1007/s12275-012-2273-4

Kang, S.-M., Khan, A. L., You, Y.-H., Kim, J.-G., Kamran, M., and Lee, I.-J. (2014a). Gibberellin production by newly isolated strain Leifsonia soli SE134 and its potential to promote plant growth. J. Microbiol. Biotechnol. 24, 106-112. doi: $10.4014 / \mathrm{jmb} .1304 .04015$

Kang, S.-M., Radhakrishnan, R., Khan, A. L., Kim, M.-J., Park, J.-M., Kim, B.-R., et al. (2014b). Gibberellin secreting rhizobacterium, Pseudomonas putida $\mathrm{H}-$ 2-3 modulates the hormonal and stress physiology of soybean to improve the plant growth under saline and drought conditions. Plant Physiol. Biochem. 84, 115-124. doi: 10.1016/j.plaphy.2014.09.001

Kaplan, D., Maymon, M., Agapakis, C. M., Lee, A., Wang, A., Prigge, B. A., et al. (2013). A survey of the microbial community in the rhizosphere of two dominant shrubs of the Negev Desert highlands, Zygophyllum dumosum (Zygophyllaceae) and Atriplex halimus (Amaranthaceae), using cultivationdependent and cultivation-independent methods. Am. J. Bot. 100, 1713-1725. doi: $10.3732 /$ ajb.1200615

Kapoor, R., and Kaur, M. (2016). Cytokinins production by fluorescent Pseudomonas isolated from rhizospheric soils of Malus and Pyrus. Afr. J. Microbiol. Res. 10, 1274-1279. doi: 10.5897/AJMR2016.8211

Kausar, R., and Shahzad, S. M. (2006). Effect of ACC-deaminase containing rhizobacteria on growth promotion of maize under salinity stress. J Agric. Soc. Sci. 2, 216-218.

Kaushal, M., and Wani, S. P. (2016). Rhizobacterial-plant interactions: strategies ensuring plant growth promotion under drought and salinity stress. Agric. Ecosyst. Environ. 231, 68-78. doi: 10.1016/j.agee.2016.06.031

Kawasaki, S., Borchert, C., Deyholos, M., Wang, H., Brazille, S., Kawai, K., et al. (2001). Gene expression profiles during the initial phase of salt stress in rice. Plant Cell 13, 889-905. doi: 10.1105/tpc.13.4.889
Khan, M. A., Boër, B., Özturk,, M., Clüsener-Godt, M., Gul, B., and Breckle, S.-W. (2016). Sabkha Ecosystems: Vol. V: The Americas. Springer.

Khan, M. S., Zaidi, A., Wani, P. A., Ahemad, M., and Oves, M. (2009). "Functional diversity among plant growth-promoting rhizobacteria: current status," in Microbial Strategies for Crop Improvement, eds M. S. Khan, A. Zaidi, and J. Musarrat (Berlin; Heidelberg: Springer), 105-132.

Kim, K., Jang, Y.-J., Lee, S.-M., Oh, B.-T., Chae, J.-C., and Lee, K.-J. (2014), Alleviation of salt stress by Enterobacter sp. EJ01 in tomato and Arabidopsis is accompanied by up-regulation of conserved salinity responsive factors in plants. Mol. Cells 37, 109-117. doi: 10.14348/molcells.2014.2239

Kloepper, J. W., Leong, J., Teintze, M., and Schroth, M. N. (1980). Enhanced plant growth by siderophores produced by plant growth-promoting rhizobacteria. Nature 286, 885-886. doi: 10.1038/286885a0

Kobayashi, T., and Nishizawa, N. K. (2012). Iron uptake, translocation, and regulation in higher plants. Annu. Rev. Plant Biol. 63, 131-152. doi: 10.1146/annurev-arplant-042811-105522

Kosová, K., Vítámvás, P., Urban, M. O., and Prášil, I. T. (2013). Plant proteome responses to salinity stress-comparison of glycophytes and halophytes. Funct. Plant Biol. 40, 775-786. doi: 10.1071/FP12375

Krishna, G., Singh, B. K., Kim, E. K., Morya, V. K., and Ramteke, P. W. (2015), Progress in genetic engineering of peanut (Arachis hypogaea L.) - A review. Plant Biotechnol. J. 13, 147-162. doi: 10.1111/pbi.12339

Ksouri, R., Ksouri, W. M., Jallali, I., Debez, A., Magné, C., Hiroko, I., et al. (2012). Medicinal halophytes: potent source of health promoting biomolecules with medical, nutraceutical and food applications. Crit. Rev. Biotechnol. 32, 289-326. doi: 10.3109/07388551.2011.630647

Kumari, A., Das, P., Parida, A. K., and Agarwal, P. K. (2015). Proteomics, metabolomics, and ionomics perspectives of salinity tolerance in halophytes. Front. Plant Sci. 6:537. doi: 10.3389/fpls.2015.00537

Larsen, H. (1986). Halophilic and halotolerant microorganisms-an overview and historical perspective. FEMS Microbiol. Lett. 39, 3-7. doi: 10.1111/j.1574-6968.1986.tb01835.x

Lau, J. A., and Lennon, J. T. (2012). Rapid responses of soil microorganisms improve plant fitness in novel environments. Proc. Natl. Acad. Sci. 109, 14058-14062. doi: 10.1073/pnas.1202319109

Lee, K.-E., Radhakrishnan, R., Kang, S.-M., You, Y.-H., Joo, G.-J., Lee, I.-J., et al. (2015). Enterococcus faecium LKE12 cell-free extract accelerates host plant growth via gibberellin and indole-3-acetic acid secretion. J. Microbiol. Biotechnol. 25, 1467-1475. doi: 10.4014/jmb.1502.02011

Leifert, C., Waites, W. M., and Nicholas, J. R. (1989). Bacterial contaminants of micropropagated plant cultures. J. Appl. Bacteriol. 67, 353-361. doi: 10.1111/j.1365-2672.1989.tb02505.x

Li, Y., Gu, Y., Li, J., Xu, M., Wei, Q., and Wang, Y. (2015a). Biocontrol agent Bacillus amyloliquefaciens LJ02 induces systemic resistance against cucurbits powdery mildew. Front. Microbiol. 6:883. doi: 10.3389/fmicb.2015.00883

Li, Z., Chang, S., Ye, S., Chen, M., Lin, L., Li, Y., et al. (2015b). Differentiation of 1aminocyclopropane-1-carboxylate (ACC) deaminase from its homologs is the key for identifying bacteria containing ACC deaminase. FEMS Microbiol. Ecol. 91:fiv112. doi: 10.1093/femsec/fiv112

Lim, G. H., Zhang, X., Chung, M. S., Lee, D. J., Woo, Y. M., Cheong, H. S., et al. (2010). A putative novel transcription factor, AtSKIP, is involved in abscisic acid signalling and confers salt and osmotic tolerance in Arabidopsis. New Phytol. 185, 103-113. doi: 10.1111/j.1469-8137.2009.03032.x

Liu, F., Xing, S., Ma, H., Du, Z., and Ma, B. (2013). Cytokinin-producing, plant growth-promoting rhizobacteria that confer resistance to drought stress in Platycladus orientalis container seedlings. Appl. Microbiol. Biotechnol. 97, 9155-9164. doi: 10.1007/s00253-013-5193-2

Lucero, M. E., Barrow, J. R., Osuna, P., Reyes, I., and Duke, S. E. (2008). Enhancing native grass productivity by cocultivating with endophyte-laden calli. Rangeland Ecol. Manage. 61, 124-130. doi: 10.2111/06-144R3.1

Lucero, M. E., Unc, A., Cooke, P., Dowd, S., and Sun, S. (2011). Endophyte microbiome diversity in micropropagated Atriplex canescens and Atriplex torreyi var griffithsii. PLoS ONE 6:e17693. doi: 10.1371/journal.pone.0017693

Ma, W., Penrose, D. M., and Glick, B. R. (2002). Strategies used by rhizobia to lower plant ethylene levels and increase nodulation. Can. J. Microbiol. 48, 947-954. doi: 10.1139/w02-100

Magome, H., and Kamiya, Y. (2016). "Inactivation processes: Gibberellins," in Annual Plant Reviews, Vol. 49, eds P. Hedden and S. G. Thomas 
(Chichester: John Wiley \& Sons) 73-94. doi: 10.1002/9781119210 436.ch3

Mahajan, S., and Tuteja, N. (2005). Cold, salinity and drought stresses: an overview. Arch. Biochem. Biophys. 444, 139-158. doi: 10.1016/j.abb.2005.10.018

Manchanda, G., and Garg, N. (2008). Salinity and its effects on the functional biology of legumes. Acta Physiol. Plant. 30, 595-618. doi: 10.1007/s11738-008-0173-3

Manousaki, E., and Kalogerakis, N. (2011). Halophytes present new opportunities in phytoremediation of heavy metals and saline soils. Ind. Eng. Chem. Res. 50, 656-660. doi: 10.1021/ie100270x

Mapelli, F., Marasco, R., Rolli, E., Barbato, M., Cherif, H., Guesmi, A., et al. (2013). Potential for plant growth promotion of rhizobacteria associated with Salicornia growing in Tunisian hypersaline soils. Biomed Res. Int. 2013:248078. doi: $10.1155 / 2013 / 248078$

Marasco, R., Rolli, E., Ettoumi, B., Vigani, G., Mapelli, F., Borin, S., et al. (2012). A drought resistance-promoting microbiome is selected by root system under desert farming. PLoS ONE 7:e48479. doi: 10.1371/journal.pone.00 48479

Martínez, C., Espinosa-Ruiz, A., and Prat, S. (2016). Gibberellins and plant vegetative growth. Annu. Plant Rev. 49, 285-322. doi: 10.1002/9781119210436.ch10

Marulanda, A., Azcón, R., Chaumont, F., Ruiz-Lozano, J. M., and Aroca, R. (2010). Regulation of plasma membrane aquaporins by inoculation with a Bacillus megaterium strain in maize (Zea mays L.) plants under unstressed and salt-stressed conditions. Planta 232, 533-543. doi: 10.1007/s00425-010-1196-8

Mayak, S., Tirosh, T., and Glick, B. R. (2004a). Plant growth-promoting bacteria confer resistance in tomato plants to salt stress. Plant Physiol. Biochem. 42, 565-572. doi: 10.1016/j.plaphy.2004.05.009

Mayak, S., Tirosh, T., and Glick, B. R. (2004b). Plant growth-promoting bacteria that confer resistance to water stress in tomatoes and peppers. Plant Sci. 166, 525-530. doi: 10.1016/j.plantsci.2003.10.025

Moshelion, M., Halperin, O., Wallach, R., Oren, R. A. M., and Way, D. A. (2015). Role of aquaporins in determining transpiration and photosynthesis in waterstressed plants: crop water-use efficiency, growth and yield. Plant Cell Environ. 38, 1785-1793. doi: $10.1111 /$ pce. 12410

Munns, R. (2002). Comparative physiology of salt and water stress. Plant Cell Environ. 25, 239-250. doi: 10.1046/j.0016-8025.2001.00808.x

Munns, R., and Tester, M. (2008). Mechanisms of salinity tolerance. Annu. Rev. Plant Biol. 59, 651-681. doi: 10.1146/annurev.arplant.59.032607.092911

Nabti, E., Sahnoune, M., Ghoul, M., Fischer, D., Hofmann, A., Rothballer, M., et al. (2010). Restoration of growth of durum wheat (Triticum durum var. waha) under saline conditions due to inoculation with the rhizosphere bacterium Azospirillum brasilense $\mathrm{NH}$ and extracts of the marine alga Ulva lactuca. J. Plant Growth Regul. 29, 6-22. doi: 10.1007/s00344-009-9107-6

Nabti, E., Schmid, M., and Hartmann, A. (2015). "Application of halotolerant bacteria to restore plant growth under salt stress," in Halophiles, eds D. K. Maheshwari and M. Saraf (Cham: Springer), 235-259.

Nadeem, S. M., Zahir, Z. A., Naveed, M., and Ashraf, M. (2010). Microbial ACCdeaminase: prospects and applications for inducing salt tolerance in plants. CRC Crit. Rev. Plant Sci. 29, 360-393. doi: 10.1080/07352689.2010.524518

Naidoo, G. (1987). Effects of salinity and nitrogen on growth and water relations in the mangrove, Avicennia marina (Forsk.) Vierh. New Phytol. 107, 317-325. doi: 10.1111/j.1469-8137.1987.tb00183.x

Nandi, M., Selin, C., Brawerman, G., Fernando, W. G. D., and de Kievit, T. (2017). Hydrogen cyanide, which contributes to Pseudomonas chlororaphis strain PA23 biocontrol, is upregulated in the presence of glycine. Biol. Control 108, 47-54. doi: 10.1016/j.biocontrol.2017.02.008

Navarro-Torre, S., Barcia-Piedras, J. M., Mateos-Naranjo, E., Redondo-Gómez, S., Camacho, M., Caviedes, M. A., et al. (2017). Assessing the role of endophytic bacteria in the halophyte Arthrocnemum macrostachyum salt tolerance. Plant Biol. 19, 249-256. doi: 10.1111/plb.12521

Naz, I., Bano, A., and Ul-Hassan, T. (2009). Isolation of phytohormones producing plant growth promoting rhizobacteria from weeds growing in Khewra salt range, Pakistan and their implication in providing salt tolerance to Glycine max L. Afr. J. Biotechnol. 8, 5762-5768. doi: 10.5897/AJB09.1176

Niehaus, F., Bertoldo, C., Kähler, M., and Antranikian, G. (1999). Extremophiles as a source of novel enzymes for industrial application. Appl. Microbiol. Biotechnol. 51, 711-729. doi: 10.1007/s002530051456
Nikolic, B., Schwab, H., and Sessitsch, A. (2011). Metagenomic analysis of the 1-aminocyclopropane-1-carboxylate deaminase gene (acdS) operon of an uncultured bacterial endophyte colonizing Solanum tuberosum L. Arch. Microbiol. 193, 665-676. doi: 10.1007/s00203-011-0703-Z

Nunkaew, T., Kantachote, D., Nitoda, T., Kanzaki, H., and Ritchie, R. J. (2015). Characterization of exopolymeric substances from selected Rhodopseudomonas palustris strains and their ability to adsorb sodium ions. Carbohydr. Polym. 115, 334-341. doi: 10.1016/j.carbpol.2014.08.099

O’Brien, J. A., and Benková, E. (2013). Cytokinin cross-talking during biotic and abiotic stress responses. Front. Plant Sci. 4:451. doi: 10.3389/fpls.2013.00451

Olanrewaju, O. S., Glick, B. R., and Babalola, O. O. (2017). Mechanisms of action of plant growth promoting bacteria. World J. Microbiol. Biotechnol. 33:197. doi: 10.1007/s11274-017-2364-9

Orhan, F. (2016). Alleviation of salt stress by halotolerant and halophilic plant growth-promoting bacteria in wheat (Triticum aestivum). Braz. J. Microbiol. 47, 621-627. doi: 10.1016/j.bjm.2016.04.001

Ozawa, T., Wu, J., and Fujii, S. (2007). Effect of inoculation with a strain of Pseudomonas pseudoalcaligenes isolated from the endorhizosphere of Salicornia europea on salt tolerance of the glasswort. Soil Sci. Plant Nutr. 53, 12-16. doi: 10.1111/j.1747-0765.2007.00098.x

Ozgur, R., Uzilday, B., Sekmen, A. H., and Turkan, I. (2013). Reactive oxygen species regulation and antioxidant defence in halophytes. Funct. Plant Biol. 40, 832-847. doi: 10.1071/FP12389

Pallai, R., Hynes, R. K., Verma, B., and Nelson, L. M. (2012). Phytohormone production and colonization of canola (Brassica napus L.) roots by Pseudomonas fluorescens 6-8 under gnotobiotic conditions. Can. J. Microbiol. 58, 170-178. doi: 10.1139/w11-120

Pang, Q., Chen, S., Dai, S., Chen, Y., Wang, Y., and Yan, X. (2010). Comparative proteomics of salt tolerance in Arabidopsis thaliana and Thellungiella halophila. J. Proteome Res. 9, 2584-2599. doi: 10.1021/pr100034f

Parida, A. K., and Das, A. B. (2005). Salt tolerance and salinity effects on plants: a review. Ecotoxicol. Environ. Saf. 60, 324-349. doi: 10.1016/j.ecoenv.2004.06.010

Paul, D., and Nair, S. (2008). Stress adaptations in a plant growth promoting rhizobacterium (PGPR) with increasing salinity in the coastal agricultural soils. J. Basic Microbiol. 48, 378-384. doi: 10.1002/jobm.200700365

Penrose, D. M., and Glick, B. R. (2003). Methods for isolating and characterizing ACC deaminase-containing plant growth-promoting rhizobacteria. Physiol. Plant. 118, 10-15. doi: 10.1034/j.1399-3054.2003.00086.x

Pérez-Alfocea, F., Albacete, A., Ghanem, M. E., and Dodd, I. C. (2010). Hormonal regulation of source-sink relations to maintain crop productivity under salinity: a case study of root-to-shoot signalling in tomato. Funct. Plant Biol. 37, 592-603. doi: 10.1071/FP10012

Piccoli, P., Travaglia, C., Cohen, A., Sosa, L., Cornejo, P., Masuelli, R., et al. (2011). An endophytic bacterium isolated from roots of the halophyte Prosopis strombulifera produces ABA, IAA, gibberellins A1 and A3 and jasmonic acid in chemically-defined culture medium. Plant Growth Regul. 64, 207-210. doi: $10.1007 /$ s10725-010-9536-z

Pierik, R., Sasidharan, R., and Voesenek, L. A. C. J. (2007). Growth control by ethylene: adjusting phenotypes to the environment. J. Plant Growth Regul. 26, 188-200. doi: 10.1007/s00344-006-0124-4

Pieterse, C. M. J., Van der Does, D., Zamioudis, C., Leon-Reyes, A., and Van Wees, S. C. M. (2012). Hormonal modulation of plant immunity. Annu. Rev. Cell Dev. Biol. 28, 489-521. doi: 10.1146/annurev-cellbio-092910-154055

Pieterse, C. M. J., Zamioudis, C., Berendsen, R. L., Weller, D. M., Van Wees, S. C. M., and Bakker, P. A. H. M. (2014). Induced systemic resistance by beneficial microbes. Annu. Rev. Phytopathol. 52, 347-375. doi: 10.1146/annurev-phyto-082712-102340

Porcel, R., Zamarreño, Á. M., García-Mina, J. M., and Aroca, R. (2014). Involvement of plant endogenous ABA in Bacillus megaterium PGPR activity in tomato plants. BMC Plant Biol. 14:36. doi: 10.1186/1471-2229-14-36

Qadir, M., Tubeileh, A., Akhtar, J., Larbi, A., Minhas, P. S., and Khan, M. A. (2008). Productivity enhancement of salt-affected environments through crop diversification. Land Degrad. Dev. 19, 429-453. doi: 10.1002/ldr.853

Qin, S., Zhang, Y.-J., Yuan, B., Xu, P.-Y., Xing, K., Wang, J., et al. (2014). Isolation of ACC deaminase-producing habitat-adapted symbiotic bacteria associated with halophyte Limonium sinense (Girard) Kuntze and evaluating their plant growth-promoting activity under salt stress. Plant Soil 374, 753-766. doi: $10.1007 / \mathrm{s} 11104-013-1918-3$ 
Qin, Y., Druzhinina, I. S., Pan, X., and Yuan, Z. (2016). Microbially mediated plant salt tolerance and microbiome-based solutions for saline agriculture. Biotechnol. Adv. 34, 1245-1259. doi: 10.1016/j.biotechadv.2016.08.005

Qurashi, A. W., and Sabri, A. N. (2012). Bacterial exopolysaccharide and biofilm formation stimulate chickpea growth and soil aggregation under salt stress. Braz. J. Microbiol. 43, 1183-1191. doi: 10.1590/S1517-83822012000300046

Rabhi, M., Barhoumi, Z., Ksouri, R., Abdelly, C., and Gharsalli, M. (2007). Interactive effects of salinity and iron deficiency in Medicago ciliaris. C. R. Biol. 330, 779-788. doi: 10.1016/j.crvi.2007.08.007

Raghavan, C., Ong, E. K., Dalling, M. J., and Stevenson, T. W. (2006). Regulation of genes associated with auxin, ethylene and ABA pathways by 2, 4dichlorophenoxyacetic acid in Arabidopsis. Funct. Integr. Genomics 6, 60-70. doi: 10.1007/s10142-005-0012-1

Ramadoss, D., Lakkineni, V. K., Bose, P., Ali, S., and Annapurna, K. (2013). Mitigation of salt stress in wheat seedlings by halotolerant bacteria isolated from saline habitats. SpringerPlus 2:6. doi: 10.1186/2193-1801-2-6

Reinhold, B., Hurek, T., Fendrik, I., Pot, B., Gillis, M., Kersters, K., et al. (1987). Azospirillum halopraeferens sp. nov., a nitrogen-fixing organism associated with roots of Kallar grass (Leptochloa fusca (L.) Kunth). Int. J. Syst. Evol. Microbiol. $37,43-51$.

Rodriguez, R. J., Henson, J., Van Volkenburgh, E., Hoy, M., Wright, L., Beckwith, F., et al. (2008). Stress tolerance in plants via habitat-adapted symbiosis. ISME J. 2:404. doi: 10.1038/ismej.2007.106

Rodriguez, R., and Redman, R. (2008). More than 400 million years of evolution and some plants still can't make it on their own: plant stress tolerance via fungal symbiosis. J. Exp. Bot. 59, 1109-1114. doi: 10.1093/jxb/erm342

Rohban, R., Amoozegar, M. A., and Ventosa, A. (2009). Screening and isolation of halophilic bacteria producing extracellular hydrolyses from Howz Soltan Lake, Iran. J. Ind. Microbiol. Biotechnol. 36, 333-340. doi: 10.1007/s10295-008-0500-0

Rozema, J., and Flowers, T. (2008). Crops for a salinized world. Science 322, 1478-1480. doi: 10.1126/science.1168572

Rozema, J., and Schat, H. (2013). Salt tolerance of halophytes, research questions reviewed in the perspective of saline agriculture. Environ. Exp. Bot. 92, 83-95. doi: 10.1016/j.envexpbot.2012.08.004

Rueda-Puente, E., Castellanos, T., Troyo-Diéguez, E., Díaz de León-Alvarez, J. L., and Murillo-Amador, B. (2003). Effects of a nitrogen-fixing indigenous bacterium (Klebsiella pneumoniae) on the growth and development of the halophyte Salicornia bigelovii as a new crop for saline environments. J. Agron. Crop Sci. 189, 323-332. doi: 10.1046/j.1439-037X.2003.00051.x

Rueda-Puente, E. O., Castellanos-Cervantes, T., Díaz de León-Álvarez, J. L., Preciado-Rangel, P., and Almaguer-Vargas, G. (2010). Bacterial community of rhizosphere associated to the annual halophyte Salicornia bigelovii (Torr.). Terra Latinoamericana 28, 345-353.

Ruppel, S., Franken, P., and Witzel, K. (2013). Properties of the halophyte microbiome and their implications for plant salt tolerance. Funct. Plant Biol. 40, 940-951. doi: 10.1071/FP12355

Ryu, H., and Cho, Y.-G. (2015). Plant hormones in salt stress tolerance. J. Plant Biol. 58, 147-155. doi: 10.1007/s12374-015-0103-z

Sadfi, N., Chérif, M., Fliss, I., Boudabbous, A., and Antoun, H. (2001). Evaluation of bacterial isolates from salty soils and Bacillus thuringiensis strains for the biocontrol of Fusarium dry rot of potato tubers. J. Plant Pathol. 83, 101-117. doi: 10.4454/jpp.v83i2.1118

Sadfi, N., Cherif, M., Hajlaoui, M. R., and Boudabbous, A. (2002). Biological control of the potato tubers dry rot caused by Fusarium roseum var. sambucinum under greenhouse, field and storage conditions using Bacillus spp. isolates. J. Phytopathol. 150, 640-648. doi: 10.1046/j.1439-0434.2002. 00811.x

Sadfi-Zouaoui, N., Essghaier, B., Hajlaoui, M. R., Fardeau, M.-L., Cayaol, J. L., Ollivier, B., et al. (2008). Ability of moderately halophilic bacteria to control grey mould disease on tomato fruits. J. Phytopathol. 156, 42-52. doi: 10.1111/j.1439-0434.2007.01329.x

Sáenz-Mata, J., Palacio-Rodríguez, R., Sánchez-Galván, H., and Balagurusamy, N. (2016). "Plant growth promoting rhizobacteria associated to halophytes: potential applications in agriculture," in Sabkha Ecosystems Volume V: The Americas, eds M. A. Khan, B. Boër, M. Özturk, M. Clüsener-Godt, B. Gul, and S.-W. Breckle (Cham: Springer), 411-425.

Sah, S. K., Reddy, K. R., and Li, J. (2016). Abscisic acid and abiotic stress tolerance in crop plants. Front. Plant Sci. 7:571. doi: 10.3389/fpls.2016.00571
Sahoo, R. K., Ansari, M. W., Pradhan, M., Dangar, T. K., Mohanty, S., and Tuteja, N. (2014). A novel Azotobacter vinellandii (SRI Az 3) functions in salinity stress tolerance in rice. Plant Signal. Behav. 9, 511-523. doi: 10.4161/psb. 29377

Salomon, M. V., Bottini, R., de Souza Filho, G. A., Cohen, A. C., Moreno, D., Gil, M., et al. (2014). Bacteria isolated from roots and rhizosphere of Vitis vinifera retard water losses, induce abscisic acid accumulation and synthesis of defenserelated terpenes in in vitro cultured grapevine. Physiol. Plant. 151, 359-374. doi: 10.1111/ppl.12117

Sanchez, D. H., Siahpoosh, M. R., Roessner, U., Udvardi, M., and Kopka, J. (2008). Plant metabolomics reveals conserved and divergent metabolic responses to salinity. Physiol. Plant. 132, 209-219. doi: 10.1111/j.1399-3054.2007.00993.x

Sánchez-Porro, C., Rafael, R., Soto-Ramírez, N., Márquez, M. C., MontalvoRodríguez, R., and Ventosa, A. (2009). Description of Kushneria aurantia gen. nov., sp. nov., a novel member of the family Halomonadaceae, and a proposal for reclassification of Halomonas marisflavi as Kushneria marisflavi comb. nov., of Halomonas indalinina as Kushneria indalinina comb. nov. and of Halomonas avicenniae as Kushneria avicenniae comb. nov. Int. J. Syst. Evol. Microbiol. 59, 397-405. doi: 10.1099/ijs.0.001461-0

Sandhya, V., Ali, S. Z., Venkateswarlu, B., Reddy, G., and Grover, M. (2010). Effect of osmotic stress on plant growth promoting Pseudomonas spp. Arch. Microbiol. 192, 867-876. doi: 10.1007/s00203-010-0613-5

Schubert, S., Neubert, A., Schierholt, A., Sümer, A., and Zörb, C. (2009). Development of salt-resistant maize hybrids: the combination of physiological strategies using conventional breeding methods. Plant Sci. 177, 196-202. doi: $10.1016 /$ j.plantsci.2009.05.011

Sgroy, V., Cassán, F., Masciarelli, O., Del Papa, M. F., Lagares, A., and Luna, V. (2009). Isolation and characterization of endophytic plant growth-promoting (PGPB) or stress homeostasis-regulating (PSHB) bacteria associated to the halophyte Prosopis strombulifera. Appl. Microbiol. Biotechnol. 85, 371-381. doi: 10.1007/s00253-009-2116-3

Shabala, S. (2013). Learning from halophytes: physiological basis and strategies to improve abiotic stress tolerance in crops. Ann. Bot. 112, 1209-1221. doi: $10.1093 / \mathrm{aob} / \mathrm{mct} 205$

Shabala, S. N., and Mackay, A. S. (2011). Ion transport in halophytes. Adv. Bot. Res. 57, 151-187. doi: 10.1016/B978-0-12-387692-8.00005-9

Shaharoona, B., Arshad, M., and Zahir, Z. A. (2006). Effect of plant growth promoting rhizobacteria containing ACC-deaminase on maize (Zea mays L.) growth under axenic conditions and on nodulation in mung bean (Vigna radiata L.). Lett. Appl. Microbiol. 42, 155-159. doi: 10.1111/j.1472-765X.2005.01827.x

Shahzad, R., Waqas, M., Khan, A. L., Asaf, S., Khan, M. A., Kang, S.-M., et al. (2016). Seed-borne endophytic Bacillus amyloliquefaciens RWL-1 produces gibberellins and regulates endogenous phytohormones of Oryza sativa. Plant Physiol. Biochem. 106, 236-243. doi: 10.1016/j.plaphy.2016.05.006

Sharma, S. B., Sayyed, R. Z., Trivedi, M. H., and Gobi, T. A. (2013). Phosphate solubilizing microbes: sustainable approach for managing phosphorus deficiency in agricultural soils. SpringerPlus 2:587. doi: 10.1186/2193-1801-2-587

Sharma, S., Kulkarni, J., and Jha, B. (2016). Halotolerant rhizobacteria promote growth and enhance salinity tolerance in peanut. Front. Microbiol. 7:1600. doi: $10.3389 /$ fmicb. 2016.01600

Shen, X., Hu, H., Peng, H., Wang, W., and Zhang, X. (2013). Comparative genomic analysis of four representative plant growth-promoting rhizobacteria in Pseudomonas. BMC Genomics 14:271. doi: 10.1186/1471-2164-14-271

Shi, W., Takano, T., and Liu, S. (2012). Isolation and characterization of novel bacterial taxa from extreme alkali-saline soil. World J. Microbiol. Biotechnol. 28, 2147-2157. doi: 10.1007/s11274-012-1020-7

Shrivastava, P., and Kumar, R. (2015). Soil salinity: a serious environmental issue and plant growth promoting bacteria as one of the tools for its alleviation. Saudi J. Biol. Sci. 22, 123-131. doi: 10.1016/j.sjbs.2014.12.001

Shukla, P. S., Agarwal, P. K., and Jha, B. (2012). Improved salinity tolerance of Arachishypogaea (L.) by the interaction of halotolerant plantgrowth-promoting rhizobacteria. J. Plant Growth Regul. 31, 195-206. doi: 10.1007/s00344-011-9231-y

Siddikee, M. A., Glick, B. R., Chauhan, P. S., Jong Yim, W., and Sa, T. (2011). Enhancement of growth and salt tolerance of red pepper seedlings (Capsicum annuum L.) by regulating stress ethylene synthesis with halotolerant bacteria 
containing 1-aminocyclopropane-1-carboxylic acid deaminase activity. Plant Physiol. Biochem. 49, 427-434. doi: 10.1016/j.plaphy.2011.01.015

Siddikee, M. A., Chauhan, P. S., Anandham, R., Han, G.-H., and Sa, T. (2010). Isolation, characterization, and use for plant growth promotion under salt stress, of ACC deaminase-producing halotolerant bacteria derived from coastal soil. J. Microbiol. Biotechnol. 20, 1577-1584. doi: 10.4014/jmb.1007.07011

Singh, G., and Jain, S. (1982). Effect of some growth regulators on certain biochemical parameters during seed development in chickpea under salinity. Indian J. Plant Physiol. 25, 167-179.

Singh, R. P., and Jha, P. N. (2016). A halotolerant bacterium Bacillus licheniformis HSW-16 augments induced systemic tolerance to salt stress in wheat plant (Triticum aestivum). Front. Plant Sci. 7:1890. doi: 10.3389/fpls.2016.01890

Singh, R. P., Shelke, G. M., Kumar, A., and Jha, P. N. (2015). Biochemistry and genetics of ACC deaminase: a weapon to "stress ethylene" produced in plants. Front. Microbiol. 6:937. doi: 10.3389/fmicb.2015.00937

Singh, U. P., Sarma, B. K., and Singh, D. P. (2003). Effect of plant growthpromoting rhizobacteria and culture filtrate of Sclerotium rolfsii on phenolic and salicylic acid contents in chickpea (Cicer arietinum). Curr. Microbiol. 46, 0131-0140. doi: 10.1007/s00284-002-3834-2

Slama, I., Abdelly, C., Bouchereau, A., Flowers, T., and Savouré, A. (2015). Diversity, distribution and roles of osmoprotective compounds accumulated in halophytes under abiotic stress. Ann. Bot. 115, 433-447. doi: $10.1093 / \mathrm{aob} / \mathrm{mcu} 239$

Sobhanian, H., Aghaei, K., and Komatsu, S. (2011). Changes in the plant proteome resulting from salt stress: toward the creation of salt-tolerant crops? J. Proteomics 74, 1323-1337. doi: 10.1016/j.jprot.2011.03.018

Song, J., and Wang, B. (2014). Using euhalophytes to understand salt tolerance and to develop saline agriculture: Suaeda salsa as a promising model. Ann. Bot. 115, 541-553. doi: 10.1093/aob/mcu194

Sorty, A. M., Meena, K. K., Choudhary, K., Bitla, U. M., Minhas, P. S., and Krishnani, K. K. (2016). Effect of plant growth promoting bacteria associated with halophytic weed (Psoralea corylifolia L) on germination and seedling growth of wheat under saline conditions. Appl. Biochem. Biotechnol. 180, 872-882. doi: 10.1007/s12010-016-2139-z

Stepien, P., and Johnson, G. N. (2009). Contrasting responses of photosynthesis to salt stress in the glycophyte Arabidopsis and the halophyte Thellungiella: role of the plastid terminal oxidase as an alternative electron sink. Plant Physiol. 149, 1154-1165. doi: 10.1104/pp.108.132407

Szymańska, S., Płociniczak, T., Piotrowska-Seget, Z., Złoch, M., Ruppel, S., and Hrynkiewicz, K. (2016). Metabolic potential and community structure of endophytic and rhizosphere bacteria associated with the roots of the halophyte Aster tripolium L. Microbiol. Res. 182, 68-79. doi: 10.1016/j.micres.2015.09.007

Takahashi, T., and Kakehi, J.-I. (2009). Polyamines: ubiquitous polycations with unique roles in growth and stress responses. Ann. Bot. 105, 1-6. doi: $10.1093 / \mathrm{aob} / \mathrm{mcp} 259$

Teng, S., Liu, Y., and Zhao, L. (2010). Isolation, identification and characterization of ACC deaminase-containing endophytic bacteria from halophyte Suaeda salsa. Wei Sheng Wu Xue Bao 50, 1503-1509.

Timmusk, S., El-Daim, I. A. A., Copolovici, L., Tanilas, T., Kännaste, A., Behers, L., et al. (2014). Drought-tolerance of wheat improved by rhizosphere bacteria from harsh environments: enhanced biomass production and reduced emissions of stress volatiles. PLOS ONE 9:e96086. doi: 10.1371/journal.pone.0096086

Tiwari, S., Singh, P., Tiwari, R., Meena, K. K., Yandigeri, M., Singh, D. P., et al. (2011). Salt-tolerant rhizobacteria-mediated induced tolerance in wheat (Triticum aestivum) and chemical diversity in rhizosphere enhance plant growth. Biol. Fertil. Soils 47:907. doi: 10.1007/s00374-0110598-5

Tsukanova, K. A., Chebotar, V., Meyer, J. J. M., and Bibikova, T.N. (2017). Effect of plant growth-promoting Rhizobacteria on plant hormone homeostasis. South Afr. J. Bot. 113, 91-102. doi: 10.1016/j.sajb.2017.07.007

Ullah, S., and Bano, A. (2015). Isolation of plant-growth-promoting rhizobacteria from rhizospheric soil of halophytes and their impact on maize (Zea mays L.) under induced soil salinity. Can. J. Microbiol. 61, 307-313. doi: 10.1139/cjm-2014-0668

Ullrich, W. R. (2002). "Salinity and nitrogen nutrition," in Salinity: Environment - Plants - Molecules, eds A. Läuchli and U. Lüttge (Dordrecht: Springer), 229-248.
Upadhyay, S. K., and Singh, D. P. (2015). Effect of salt-tolerant plant growthpromoting rhizobacteria on wheat plants and soil health in a saline environment. Plant Biol. 17, 288-293. doi: 10.1111/plb.12173

Upadhyay, S. K., Singh, D. P., and Saikia, R. (2009). Genetic diversity of plant growth promoting rhizobacteria isolated from rhizospheric soil of wheat under saline condition. Curr. Microbiol. 59, 489-496. doi: 10.1007/s00284-009-9464-1

Upadhyay, S. K., Singh, J. S., and Singh, D. P. (2011). Exopolysaccharide-producing plant growth-promoting rhizobacteria under salinity condition. Pedosphere 21, 214-222. doi: 10.1016/S1002-0160(11)60120-3

Uzilday, B., Ozgur, R., Sekmen, A. H., Yildiztugay, E., and Turkan, I. (2014). Changes in the alternative electron sinks and antioxidant defence in chloroplasts of the extreme halophyte Eutrema parvulum (Thellungiella parvula) under salinity. Ann. Bot. 115, 449-463. doi: 10.1093/aob/mcu184

Vacheron, J., Desbrosses, G., Bouffaud, M.-L., Touraine, B., Moënne-Loccoz, Y., Muller, D., et al. (2013). Plant growth-promoting rhizobacteria and root system functioning. Front. Plant Sci. 4:356. doi: 10.3389/fpls.2013.00356

Vaddepalli, P., Fulton, L., Wieland, J., Wassmer, K., Schaeffer, M., Ranf, S., et al. (2017). The cell wall-localized atypical $\beta-1,3$ glucanase ZERZAUST controls tissue morphogenesis in Arabidopsis thaliana. Development 144, 2259-2269. doi: 10.1242/dev.152231

Van Loon, L. C., Bakker, P., and Pieterse, C. M. J. (1998). Systemic resistance induced by rhizosphere bacteria. Annu. Rev. Phytopathol. 36, 453-483. doi: 10.1146/annurev.phyto.36.1.453

Ventosa, A., Mellado, E., Sanchez-Porro, C., and Marquez, M. C. (2008). "Halophilic and halotolerant micro-organisms from soils", in Microbiology of Extreme Soils, eds P. Dion and C. S. Nautiyal (Berlin; Heidelberg: Springer), 87-115.

Vitousek, P. M., and Howarth, R. W. (1991). Nitrogen limitation on land and in the sea: how can it occur? Biogeochemistry 13, 87-115.

Walters, D. R., Ratsep, J., and Havis, N. D. (2013). Controlling crop diseases using induced resistance: challenges for the future. J. Exp. Bot. 64, 1263-1280. doi: 10.1093/jxb/ert026

Wang, G.-L., Que, F., Xu, Z.-S., Wang, F., and Xiong, A.-S. (2015). Exogenous gibberellin altered morphology, anatomic and transcriptional regulatory networks of hormones in carrot root and shoot. BMC Plant Biol. 15:290. doi: 10.1186/s12870-015-0679-y

Wang, X., Chang, L., Wang, B., Wang, D., Li, P., Wang, L., et al. (2013). Comparative proteomics of Thellungiella halophila leaves from plants subjected to salinity reveals the importance of chloroplastic starch and soluble sugars in halophyte salt tolerance. Mol. Cell. Proteomics 12, 2174-2195. doi: $10.1074 / \mathrm{mcp} . M 112.022475$

Wang, Y., Mopper, S., and Hasenstein, K. H. (2001). Effects of salinity on endogenous ABA, IAA, JA, and SA in Iris hexagona. J. Chem. Ecol. 27, 327-342. doi: 10.1023/A:1005632506230

Watanabe, M., Kawahara, K., Sasaki, K., and Noparatnaraporn, N. (2003). Biosorption of cadmium ions using a photosynthetic bacterium, Rhodobacter sphaeroides $\mathrm{S}$ and a marine photosynthetic bacterium, Rhodovulum sp. and their biosorption kinetics. J. Biosci. Bioeng. 95, 374-378. doi: 10.1016/S1389-1723(03)80070-1

Yan, N., Marschner, P., Cao, W., Zuo, C., and Qin, W. (2015). Influence of salinity and water content on soil microorganisms. Int. Soil Water Conserv. Res. 3, 316-323. doi: 10.1016/j.iswcr.2015.11.003

Yang, J., Kloepper, J. W., and Ryu, C.-M. (2009). Rhizosphere bacteria help plants tolerate abiotic stress. Trends Plant Sci. 14, 1-4. doi: 10.1016/j.tplants.2008.10.004

Yasmin, H., and Bano, A. (2011). Isolation and characterization of phosphate solubilizing bacteria from rhizosphere soil of weeds of khewra salt range and attock. Pak. J. Bot 43, 1663-1668.

Yoon, J.-H., Choi, S. H., Lee, K.-C., Kho, Y. H., Kang, K. H., and Park, Y.H. (2001). Halomonas marisflavae sp. nov., a halophilic bacterium isolated from the Yellow Sea in Korea. Int. J. Syst. Evol. Microbiol. 51, 1171-1177. doi: 10.1099/00207713-51-3-1171

Yousfi, S., Mahmoudi, H., Abdelly, C., and Gharsalli, M. (2007). Effect of salt on physiological responses of barley to iron deficiency. Plant Physiol. Biochem. 45, 309-314. doi: 10.1016/j.plaphy.2007.03.013

Yu, J., Chen, S., Zhao, Q., Wang, T., Yang, C., Diaz, C., et al. (2011). Physiological and proteomic analysis of salinity tolerance in Puccinellia tenuiflora. J. Proteome Res. 10, 3852-3870. doi: 10.1021/pr101102p 
Yuan, Z., Druzhinina, I. S., Labbé, J., Redman, R., Qin, Y., Rodriguez, R., et al. (2016). Specialized microbiome of a halophyte and its role in helping non-host plants to withstand salinity. Sci. Rep. 6:32467. doi: 10.1038/ srep32467

Zahir, Z. A., Ghani, U., Naveed, M., Nadeem, S. M., and Asghar, H. N. (2009). Comparative effectiveness of Pseudomonas and Serratia sp. containing ACC-deaminase for improving growth and yield of wheat (Triticum aestivum L.) under salt-stressed conditions. Arch. Microbiol. 191, 415-424. doi: 10.1007/s00203-009-0466-y

Zahir, Z. A., Shah, M. K., Naveed, M., and Akhter, M. J. (2010). Substratedependent auxin production by Rhizobium phaseoli improves the growth and yield of Vigna radiata L. under salt stress conditions. J. Microbiol. Biotechnol. 20, 1288-1294. doi: 10.4014/jmb.1002. 02010

Zawoznik, M. S., Ameneiros, M., Benavides, M. P., Vázquez, S., and Groppa, M. D. (2011). Response to saline stress and aquaporin expression in Azospirilluminoculated barley seedlings. Appl. Microbiol. Biotechnol. 90, 1389-1397. doi: 10.1007/s00253-011-3162-1

Zhang, H., Kim, M.-S., Sun, Y., Dowd, S. E., Shi, H., and Paré, P. W. (2008). Soil bacteria confer plant salt tolerance by tissue-specific regulation of the sodium transporter HKT1. Mol. Plant-Microbe Interact. 21, 737-744. doi: 10.1094/MPMI-21-6-0737

Zhang, J.-L., and Shi, H. (2013). Physiological and molecular mechanisms of plant salt tolerance. Photosyn. Res. 115, 1-22. doi: 10.1007/s11120-013-9813-6

Zhao, S., Zhou, N., Zhao, Z.-Y., Zhang, K., Wu, G.-H., and Tian, C.-Y. (2016). Isolation of endophytic plant growth-promoting bacteria associated with the halophyte Salicornia europaea and evaluation of their promoting activity under salt stress. Curr. Microbiol. 73, 574-581. doi: 10.1007/s00284-0161096-7
Zhou, M., Chen, W., Chen, H., and Wei, G. (2012). Draft genome sequence of Mesorhizobium alhagi CCNWXJ12-2T, a novel salt-resistant species isolated from the Desert of Northwestern China. J. Bacteriol. 194, 1261-1262. doi: 10.1128/JB.06635-11

Zhou, N., Zhao, S., and Tian, C. Y. (2017). Effect of halotolerant rhizobacteria isolated from halophytes on the growth of sugar beet (Beta vulgaris L.) under salt stress. FEMS Microbiol. Lett. 364:fnx091. doi: 10.1093/femsle/fnx091

Zhu, F., Qu, L., Hong, X., and Sun, X. (2011). Isolation and characterization of a phosphate-solubilizing halophilic bacterium Kushneria sp. YCWA18 from Daqiao Saltern on the coast of Yellow Sea of China. Evid. Based Complement. Altern. Med. 2011:615032. doi: 10.1155/2011/615032

Zhu, Y., Shearer, G., and Kohl, D. H. (1992). Proline fed to intact soybean plants influences acetylene reducing activity and content and metabolism of proline in bacteroids. Plant Physiol. 98, 1020-1028. doi: 10.1104/pp.98.3.1020

Zuccarini, P., and Okurowska, P. (2008). Effects of mycorrhizal colonization and fertilization on growth and photosynthesis of sweet basil under salt stress. J. Plant Nutr. 31, 497-513. doi: 10.1080/01904160801 895027

Conflict of Interest Statement: The authors declare that the research was conducted in the absence of any commercial or financial relationships that could be construed as a potential conflict of interest.

Copyright (c) 2018 Etesami and Beattie. This is an open-access article distributed under the terms of the Creative Commons Attribution License (CC BY). The use, distribution or reproduction in other forums is permitted, provided the original author(s) and the copyright owner are credited and that the original publication in this journal is cited, in accordance with accepted academic practice. No use, distribution or reproduction is permitted which does not comply with these terms. 